\section{Circulating microRNAs in insulin resistant horses and ponies}

\section{MicroRNAs circulantes em cavalos e pônies com resistência à insulina}

\author{
Hugo Felipe da Costa Santos ${ }^{1}$ (D) Tanja Maria Hess²* (D), Jason Brummer ${ }^{1}$ (D) , Peter Graham¹, Brigett Mcintosh ${ }^{3}$ \& \\ Rebecca Splan ${ }^{4}$ (D) \\ 'Zootechnist, PhD., Colorado State University (CSU), Fort Collins, CO, United States \\ 2 Veterinarian, PhD., Colorado State University (CSU), Fort Collins, CO, United States \\ ${ }^{3}$ Zootechnist, PhD., Mars Incorporated (Equine Sponsorship) and Virginia Polytechnic State and Institute, Middleburg, VA, \\ United States \\ ${ }^{3}$ Zootechnist, PhD., Delaware Valley University (Equine Science \& Management), Doylestown, PA, United States
}

\begin{abstract}
Insulin resistance is a prevalent disorder among horses and is associated with abnormal adiposity, laminitis, equine metabolic syndrome, and pituitary pars intermedia dysfunction. The processes leading to equine insulin resistance and associated conditions remain subject for study. MicroRNAs (miRNAs) are involved in regulation of many biological processes and diseases. The current study aimed to investigate the circulating miRNA profile of insulin resistant horses and ponies. It was hypothesized that insulin resistant horses would have a different circulating miRNA profile compared to healthy ones. 12 Thoroughbred/ Thoroughbred-cross and 12 Welsh/Dartmoor non-pregnant mares were evaluated for insulin sensitivity using frequent sampling intravenous glucose tolerance test (FSIGTT). Serum samples were collected for miRNA profiling through RT-qPCR analysis. Horses and ponies were divided into insulin sensitive (IS) or insulin resistant (IR) groups and their miRNA profiles compared. Results demonstrated that 13 miRNAs were differently expressed between IR and IS horses, 15 between IR and IS ponies, 17 between horses and ponies, and 10 between IR and IS animals (horses and ponies combined) ( $p<0.05$ ). Finally, 8 miRNAs were proposed as potential regulators of equine insulin resistance. miRNA profiling is a potential tool to evaluate insulin resistance and associated conditions.
\end{abstract}

Keywords: equine metabolic syndrome, insulin resistance, laminitis, microRNA.

\section{Resumo}

Resistência à insulina é um problema prevalente em cavalos associado à adiposidade excessiva, síndrome metabólica, laminite e adenoma da parte intermédia da pituitária. A fisiopatologia que leva à resistência à insulina e doenças associadas é assunto de grande interesse na pesquisa. Micro RNAs (miRNAs) são envolvidos na regulação de diversos processos biológicos e doenças. O presente estudo tem como objetivo avaliar o perfil de miRNAs circulante em cavalos e pôneis com resistência à insulina. Nossa hipótese principal é que cavalos com resistência à insulina tem um perfil circulatório diferente de animais normais. Doze cavalos da raça Puro Sangue Inglês (PSI) e cruza PSI e doze pôneis da raça Welsh e Dartmoor foram avaliados quanto a sua sensibilidade à insulina usando o teste de tolerância à glicose intravenosa de coletas frequentes. Amostras de soro foram coletadas para determinação do perfil de miRNA a partir da análise de RT-qPCR. Cavalos e pôneis foram divididos em grupos de animais sensíveis (IS) e resistentes à insulina (RI). Análise dos resultados demonstraram 13 miRNA tiveram expressão diferente entre cavalos IS e IR, 15 diferentes entre pôneis IS e IR, 17 miRNA diferentes entre pôneis e cavalos, e 10 miRNA diferentes entre animais IS e IR (pôneis e cavalos combinados) ( $p<0.05$ ). Oito destes miRNA são reguladores de resistência à insulina. O perfil de miRNA pode ser usado como ferramenta para o maior entendimento dos mecanismos que levam a resistência à insulina e patologias associadas

Palavras-chave: síndrome metabólica equina, resistência à insulina, laminite, microRNA.

\section{B] $\mathbf{M}$ \\ Brazilian Journal of Veterinary Medicine \\ p-ISSN 0100-2430

How to cite: Santos, H. F.C., Hess, T. M., Brummer J., Graham, P., Mcintosh, B., \& Splan, R. (2021) Circulating microRNAs in insulin resistant horses and ponies. Brazilian Journal of Veterinary Medicine, 43, e003620. https://doi.org/10.29374/25272179.bjvm003620

Received: December 31, 2020.

Accepted: April 16, 2021.

\section{*Correspondence}

Tanja Maria Hess

Department of Animal Sciences, Colorado

State University

735 South Overland Trail

Fort Collins, CO 80523

E-mail: tanja.hess@colostate.edu
Copyright Santos et al. This is an Open Access article distributed under the terms of the Creative Commons Attribution Non-Commercial License, which permits unrestricted non-commercial use, distribution and reproduction in any medium provided the original work is properly cited. 


\section{Introduction}

Insulin is a hormone secreted by pancreatic beta-cells that regulates energy homeostasis in various organs, particularly muscle, adipose tissue, and liver (Vick et al., 2007; Nirmalan \& Nirmalan, 2017). Insulin also promotes cell division and growth (Wilcox, 2005). Insulin secretion is controlled by many factors (DeFronzo et al., 1979; Pfeifer et al., 1981) and interferences in its action can lead to detrimental conditions (Sah et al., 2016).

In the horse, insulin resistance has been associated with obesity and regional adiposity, chronic low-grade systemic inflammation, equine metabolic syndrome, pituitary pars intermedia dysfunction, and endocrinopathic laminitis (Frank et al., 2010). However, the mechanisms causing these conditions are not completely clarified, demanding more research in the area.

Evidence has verified that microRNAs (miRNAs), a class of small non-coding RNA molecules, play important roles in a variety of biological processes and diseases (Ardekani \& Naeini, 2010). It has been suggested that circulating miRNAs serve as long-distance communicators between tissues (Mao et al., 2013), and they have great potential as efficient tools in studying disease-related conditions such as type 2 diabetes and metabolic syndrome in humans and laboratory animals (Ortega et al., 2014; Cui et al., 2018).

In a preliminary study, we demonstrated that insulin resistant horses differentially express circulating miRNAs compared to healthy animals. By studying the differences in circulating miRNA profiles between insulin resistant and healthy animals, more information regarding the mechanisms surrounding this condition in equids can be gathered. This new information can lead to the discovery of potential biomarkers for diagnosing insulin resistance. The current study aimed to further investigate the association of circulating miRNA profiles to this disease in equids due to the small number of horses in our preliminary study (da Costa Santos et al., 2018). We propose that changes in miRNA profiles in equine serum lead to altered gene expression, impacting in metabolic dysfunctions, such as insulin resistance. Therefore, insulin resistance in horses and ponies would result in differential circulating miRNA profiles between healthy and IR animals. In this sense, this study aimed to compare circulating miRNAs between serums of insulin resistant and sensitive equids (1), and horses and ponies, characterize circulating miRNA profiles associated with equine insulin resistance (2), and finally (3) identify candidate genes important for equine insulin resistance and its associated conditions.

\section{Material and methods}

Animal selectionAnimals in each herd were maintained on pasture with ad libitum access to forage, water and mineral prior to the start of the study. Animals from both herds were located in Northern Virginia. Prior knowledge of two diverse but metabolically well-characterized populations (Thoroughbred/ Thoroughbred-cross horses and Welsh/Dartmoor ponies) were used to pre-select animals. These animals were screened by using proxy estimations of insulin sensitivity from single measurements of fasting glucose and insulin (Treiber et al., 2005). Based on the data from blood samples, individual animal history, and insulin sensitivity status known from previous research studies, animals were finally selected (24 animals; 12 from each herd) and divided into two main groups: twelve (six horses and six ponies) suspected to be insulin resistant (IR) and twelve (six horses and six ponies) controls suspected to be insulin sensitive (IS) matched by age, weight, breed and body condition. After pre-selection, the frequently sampled intra-venous glucose tolerance (FSIGT) test with minimal model analysis was performed to classify insulin sensitivity in those animals (Hoffman et al., 2003), and to profile circulating miRNA (Figure 1). Ponies and horses were at different properties. Animal sampling occurred in winter months to reduce variability in blood parameters or body condition due to pasture conditions and to minimize variability during statistical analysis. Additionally, only mares (non-pregnant) were used. Diets were designed to meet NRC recommendations for idle horses. Forage samples were collected and analyzed prior to animal sampling to confirm nutrient values.

\section{Ethics statement}

This study was approved by the Virginia Tech Institutional Animal Care and Use Committee. IACUC\#: 15-046, Virginia Polytechnic Institute and State University. 


\section{Thoroughbred and Thoroughbred-cross herd}

\section{Welsh and Dartmoor} Pony herd

STEP 1: For each herd, sort animals into insulin-sensitive (IS) and insulinresistant (IR) groups based on prior knowledge of metabolic status
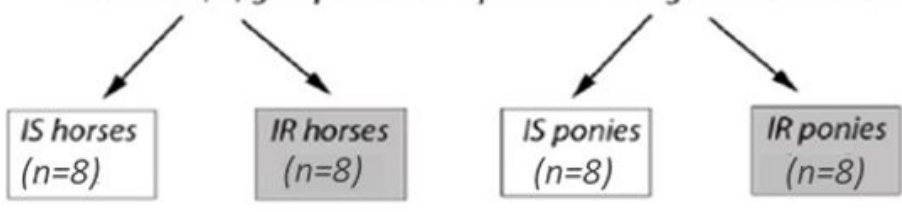

STEP 2: Screen horses and ponies using basal glucose and insulin values to select 6 animals/group to move forward to FSIGT

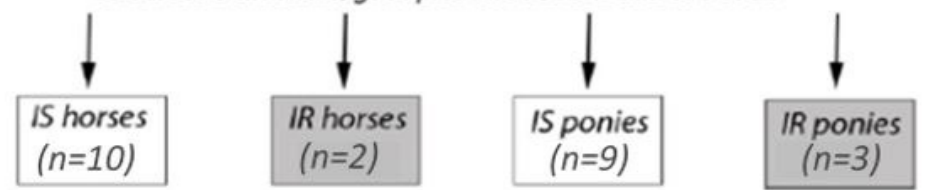

STEP 3: Perform FSIGT and associated minimal model procedures on all animals to confirm insulin sensitivity or resistance

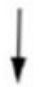

STEP 4: microRNA profiling

STEP 5: Compare microRNA expression between IS and IR animals for each of 340 microRNAs

STEP 6: Determine putative gene targets using pathway analysis<smiles>[3H][3H]</smiles>

STEP 7: Verify microRNA abundance level is associated with relative expression of 10-15 gene targets related to insulin resistance

Figure 1. Schematic illustration of research protocol used in this study.

Frequent sampling Intra venous glucose tolerance test (FSGIT) and groups description

Prior to sampling, animals were maintained overnight in stalls to maintain an unperturbed state prior to sampling. Horses were allowed ad libitum access to water and hay with known composition and low sugar content.

All FSIGT tests were performed in the morning and within the span of one week to reduce variation due to time of collection. Catheters were placed aseptically in the jugular vein one hour prior to the start of the tests. Briefly, after collection of baseline blood samples (-30 and 0 min), a $50 \% \mathrm{w} / \mathrm{v}$ dextrose solution ( $0.3 \mathrm{~g} / \mathrm{kg}$ BW administered over $2 \mathrm{~min}$ ) was infused intravenously. At $20 \mathrm{~min}$ after glucose administration, insulin (10 IU/kg BW) was infused via catheter and subsequent blood samples collected until 180 min post-glucose infusion. Sampling occurred via jugular venipuncture into $10 \mathrm{~mL}$ Vacutainer (BD, Dickinson, MA) tubes coated with EDTA (to recover plasma for insulin analysis), potassium oxalate (to recover plasma for glucose analysis) and without anticoagulant (to recover serum for miRNA profiling, taken at baseline before FSIGTT). 
Plasma was analyzed for glucose by enzymatic assay using the YSI 2700 SELECT Biochemistry Analyzer (Yellow Springs, OH) with YSI 2365 glucose membranes, YSI 2747 glucose/L-Lactate standard, and YSI 2357 buffer concentrate kit. Plasma insulin was analyzed by radioimmunoassay using Millipore Human Insulin Kit (Millipore, St Charles, Missouri), previously validated for horses (Freestone et al., 1992). Insulin levels above the kit standards were diluted with charcoal stripped equine plasma (Borer et al., 2009).

Insulin sensitivity index (SI), acute insulin response to glucose (AIRg), glucose effectiveness (Sg) and disposition index (DI) were determined by the minimal model of glucose and insulin dynamics using specialized software (MinMod Millenium 6.02) (Treiber et al., 2005). Areas under the insulin and glucose curve were calculated using Riemann sums (trapezoidal rule) (Rasmussen et al. 2017; Tai, 1994). Serum collected during the -30 min baseline measurement of the FSIGT was used for miRNA profiling analyses.

Groups were selected based on the combination of their minimal model parameters, basal glucose and basal insulin values, and estimated areas under the curve (AUC) for both glucose and insulin. The cut-off values for being considered insulin sensitive was basal insulin $<20$ and $<30 u I U / m L$ for horses and ponies, respectively (Morgan et al., 2015; McGowan et al., 2004; Frank et al., 2010).

The minimal model parameters were not very efficient diagnosing insulin resistant animals given the doses of exogenous insulin (too low) and glucose (too high) used in the test. Therefore, estimating total areas under curves for both glucose and insulin allowed a more efficient evaluation of the physiological response of glucose-insulin interactions. Normal individuals are expected to have lower estimated area under the curve values for glucose and/or insulin, while higher values are indicative of disturbances in glucose homeostasis. Furthermore, the main determining factors considered for selecting the groups were estimated area under the curves from the FSIGT test for insulin, and basal glucose and insulin (Table1, Figure2). Animals' history of previous insulin resistance metabolic state or laminitis cases were also considered when diagnosing insulin resistant animals.

Table 1. Values of basal insulin and area under the insulin curve for insulin resistant versus insulin sensitive horses and ponies.

\begin{tabular}{lcc}
\hline \multicolumn{1}{c}{ Horses } & IR & IS \\
\hline Basal Insulin $(\mathrm{uIU} / \mathrm{mL})$ & $29.2^{\mathrm{a}}(21.4 ; 40.0)$ & $12.9^{\mathrm{b}}(11.6 ; 14.4)$ \\
AUCi $(\mathbf{A U C i}, \mu \mathrm{IU} / \mathrm{mL} \times \mathrm{min})$ & $26190^{\mathrm{a}}(40174 ; 17074)$ & $5685^{\mathrm{b}}(4987 ; 6480)$ \\
\hline \multicolumn{1}{c}{ Ponies } & IR & IS \\
\hline Basal Insulin $(\mathrm{uIU} / \mathrm{mL})$ & $35.5^{\mathrm{a}}(29.3 ; 43.1)$ & $15.0^{\mathrm{b}}(11.6 ; 19.3)$ \\
AUCi $(\mathbf{A U C i}, \mu \mathrm{IU} / \mathrm{mL} \times \mathrm{min})$ & $24510^{\mathrm{a}}(21270 ; 28244)$ & $8192^{\mathrm{b}}(5,855 ; 11,463)$ \\
\hline
\end{tabular}

Values for insulin are shown as mean (95\% confidence interval). Different letters (a or b) indicate significance between insulin resistant (IR) and insulin sensitive (IS) groups ( $p<0.05)$.

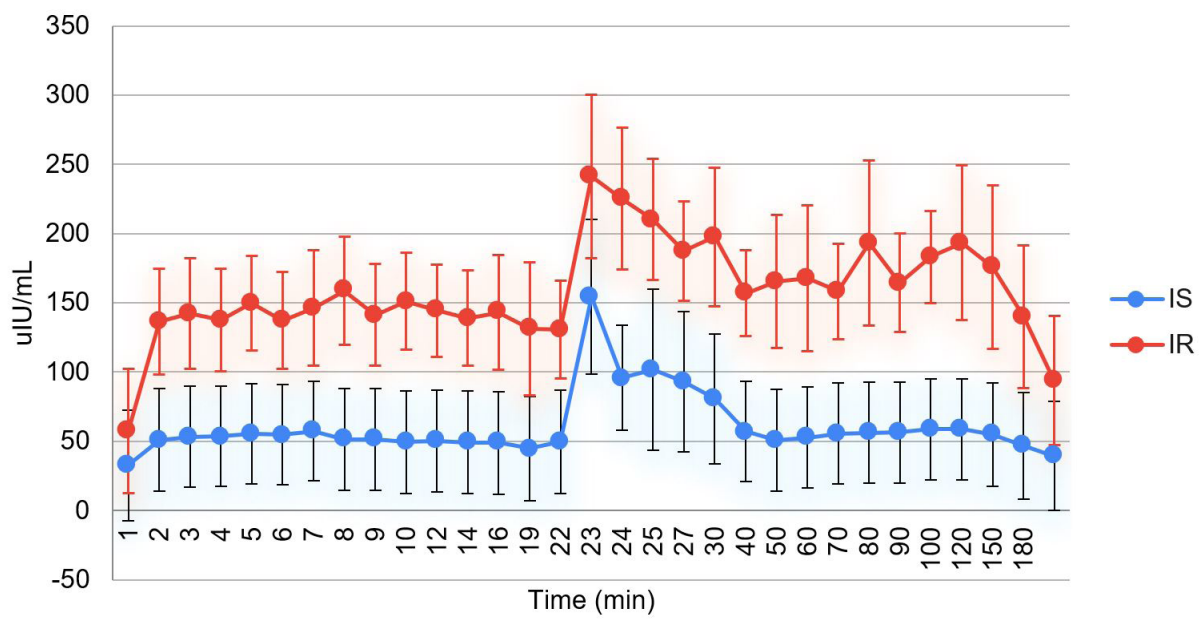

Figure 2. Plasma insulin mean and 95\%CI in insulin resistant (IR) and insulin sensitive (IS) horses during the FSIVGT 
Considering these factors all together, there were 2 horses and 9 ponies diagnosed as insulin resistant (total of 11 insulin resistant animals) and 10 horses and 3 ponies diagnosed as insulin sensitive (total of 13 insulin sensitive animals). The final data of each group can be found in the tables below, different from the pre-selected basal proxy analysis.

The selection of groups based on minimal model parameters was based on reference quintile values (Treiber et al., 2005). However, because given insulin was too low in relation to glucose administered, only the acute insulin response to glucose (AIRg) values, which quantify endogenous insulin secretion in response to the glucose dose, were considered (Treiber et al., 2005). Groups considerably differed in AIRg quintiles for the minimal model parameters for horses and for ponies (Table 2).

Table 2. Acute insulin response to glucose (AIRg, mu.1^-1.min) values, and respective quintiles, for horses and ponies.

\begin{tabular}{cccccc}
\hline Horses & \multicolumn{2}{c}{ IR } & \multicolumn{2}{c}{ IS } \\
\hline AIRg & $1022^{\mathrm{a}}(1,012 ; 1,031)$ & $5^{\text {th }}$ Quintile & $197^{\mathrm{b}}(173 ; 224)$ & $3^{\text {rd }}$ Quintile \\
\hline Ponies & & IR & & IS \\
\hline AIRg & $839^{\mathrm{a}}(736 ; 956)$ & & $5^{\text {th }}$ Quintile & $210^{\mathrm{b}}(151 ; 292)$ & $3^{\text {rd }}$ Quintile \\
\hline
\end{tabular}

Values are shown as mean (95\% confidence interval). Different letters (a or b) indicate significance between groups $(\mathrm{p}<0.05)$.

Insulin resistant and insulin sensitive horses differed for basal insulin and total area under the insulin curve but did not differ for basal glucose and total area under the glucose curve (Table 3, Figure 2).

Table 3. Values basal glucose and area under the glucose curve for insulin resistant versus insulin sensitive horses and ponies.

\begin{tabular}{lcc}
\hline \multicolumn{1}{c}{ Horses } & IR & IS \\
\hline Basal Glucose $(\mathrm{mg} / \mathrm{dL})$ & $88.4 \pm 4.5$ & $90.06 \pm 1.5$ \\
AUCg (AUCg, mg/dL $\times$ min) & $27313 \pm 12$ & $28849 \pm 12$ \\
\hline \multicolumn{1}{c}{ Ponies } & IR & IS \\
\hline Basal Glucose $(\mathrm{mg} / \mathrm{dL})$ & $88.67 \pm 2.53$ & $94.24 \pm 4.1$ \\
AUCg (AUCg, mg/dL $\times$ min) & $27476 \pm 964$ & $32730.4 \pm 3212.7$ \\
\hline
\end{tabular}

Values for glucose are shown as mean \pm standard error. Different letters (a or b) indicate significance between insulin resistant (IR) and insulin sensitive (IS) groups ( $p<0.05)$.

Insulin resistant and insulin sensitive ponies did not differ for basal glucose and total area under the glucose but differed for basal insulin and total area under the insulin curve (Tables 3 and 4). Both groups for horses and for ponies did not differ for body weight and body condition score (Table 4).

Table 4. Values of body weight (BW) and body condition score (BCS) for insulin resistant (IR) versus insulin sensitive (IS) horses and ponies.

\begin{tabular}{|c|c|c|c|c|}
\hline \multirow{2}{*}{$\begin{array}{c}\text { Parameter } \\
\text { Horses }\end{array}$} & \multicolumn{2}{|c|}{ BW (kg) } & \multicolumn{2}{|c|}{ BCS } \\
\hline & IR & IS & IR & IS \\
\hline Value & $655.5 \pm 2.5$ & $635 \pm 29$ & $7.5 \pm 0.5$ & $6.2 \pm 0.3$ \\
\hline Ponies & IR & IS & IR & IS \\
\hline Value & $321.8 \pm 21.5$ & $384 \pm 47$ & $6.8 \pm 0.25$ & $6.8 \pm 0.16$ \\
\hline
\end{tabular}

Values are shown as mean \pm standard error. 


\section{MicroRNA isolation and profiling}

Total RNA was isolated from equine serum samples according to manufacturer's protocols using TRI Reagent BD-RNA/DNA/Protein Isolation Reagent for Blood Derivatives (Molecular Research Center, Cincinnati, OH). Samples were lysed and separated by chloroform into RNA and protein layers. RNA was precipitated with isopropanol and washed with $75 \%$ ethanol. All samples were then treated with DNA-free DNase Treatment and Removal Reagent (Invitrogen/ Life Sciences, Grand Island, NY) to remove DNA contamination. RNA purity values were assessed using the Nanodrop Spectrophotometer ND-1000 (Thermo Scientific, Wilmington, DE). Samples were then stored at $-80^{\circ} \mathrm{C}$ until RT-qPCR analysis. CDNA was generated using miScript II RT Kit (Qiagen Valencia, CA) per the manufacturer's protocol. 4 $\mu \mathrm{L}$ 5X miScript RT Buffer, $1 \mu \mathrm{L}$ reverse transcriptase mix and $1 \mu \mathrm{g}$ of RNA and water were used in a $20 \mu \mathrm{L}$ solution and incubated for 60 min at $37^{\circ} \mathrm{C}$ and then $5 \mathrm{~min}$ at $95^{\circ} \mathrm{C}$. cDNA reaction was then immediately added to qRT-PCR master mix for PCR analysis (Nulton, 2014).

Equine miRNA forward primer sequences were obtained by an in silico detection model (Zhou et al., 2009) and validated in the horse via small RNA-seq. Of all the 340 equine miRNAs used in this study, 250 were conserved human miRNAs and 75 were equine-specific miRNAs with human homologues, but different nucleotide sequences. The remaining 15 miRNAs were equine-specific but had no apparent human homologue (Zhou et al., 2009).

Qiagen RT-qPCR protocol was performed on 384 well plates with three previously validated endogenous controls: RNU43, snoRNA, and U1 snRNA, a negative control (no primer), and 340 previously validated equine miRNAs [19]. Each well contained $6 \mu \mathrm{L}$ of total reaction including 2X QuantiTect SYBR Green PCR Master Mix, 10X miScript Universal reverse primer (Qiagen), and miRNA specific forward primer and $0.1 \mu \mathrm{L}$ of cDNA. RT-qPCR was performed using the LightCycler480 PCR system (Roche).

Cycle conditions run at $95^{\circ} \mathrm{C}$ for 15 minutes, followed by 45 cycles of $94^{\circ} \mathrm{C}$ for 15 seconds for denaturation, annealing at $55^{\circ} \mathrm{C}$ for 30 seconds, and extension at $70^{\circ} \mathrm{C}$ for 30 seconds, ending in a melt curve analysis to confirm single cDNA amplification. miRNAs were considered present at a cycle number of less than 37 as well as confirmed appropriate by amplification curves and singular melt peaks. Samples were run with biological and technical replicates.

\section{Normalization of miRNA Expression Data and Statistical Analysis}

Normalization was done by delta CT = Ct(target) $-\mathrm{Ct}$ (mean of sample), which has been showed to have high efficiency identifying select housekeeping genes for large-scale miRNA expression studies utilizing the geometric mean of all miRNA genes expressed in samples that had an SD $\leq 1$ (Mestdagh et al., 2009).

A Shapiro-Wilk normality test was performed to determine normal distribution. Variables were transformed and analyzed on the log scale when necessary. Two tailed t-tests were performed to compare miRNA profiles between groups. Significant results considered when p<0.05.

\section{Pathway analysis}

A posterior pathway analysis was performed with DIANA TOOLS miRPath v.3 (Vlachos et al., 2015) using miRNA differentially and uniquely expressed. Predicted targets were recorded using DIANA-microT-CDS algorithm and pathways were considered significant with $\mathrm{p} \leq 0.05$ (Reczko et al., 2012). Additional data, such as miRNA-disease associations and miRNA-gene interactions, were collected from other database sources, including DIANNA TOOLs TarBase v.8 (Karagkouni al., 2018), and DisGeNET RDF v4. (Piñero et al., 2015, 2017).

\section{Results}

\section{Pasture and hay analysis}

Results of feed analysis can be found in Table 5. Horses' and ponies' pastures had similar overall digestible energy. However, the NSC content in the diet fed to ponies was higher than the diet fed to horses. Animals had access to mix cool season pastures. However, the grass offered to horses was higher in fiber content than the grass fed to ponies. The composition of 
Table 5.Chemical analysis (on a dry matter basis) of the cool season grass pastures and hay for horses and ponies.

\begin{tabular}{lcc}
\multicolumn{1}{c}{ Analysis Parameters } & Horses & Ponies \\
\hline DM (\%) & $97(95.8 ; 98.2)$ & $95.7(95.6 ; 95.8)$ \\
DE (Mcal/Kg) & $2(1.9 ; 2.1)$ & $2.3(2.2 ; 2.4)$ \\
CP (\%) & $10.1(8 ; 12.1)$ & $18.4(14.4 ; 22.5)$ \\
Estimated Lysine (\%) & $0.4(0.3 ; 0.4)$ & $0.7(0.5 ; 0.9)$ \\
ADF (\%) & $40.7(36.1 ; 45.4)$ & $30.2(27.9 ; 32.5)$ \\
NDF (\%) & $67.3(62.6 ; 71.9)$ & $51.4(47.1 ; 55.6)$ \\
WSC (\%) & $6.3(4.3 ; 8.3)$ & $15.4(12.3 ; 18.5)$ \\
ESC (\%) & $5.4(3.5 ; 7.4)$ & $11.4(9.8 ; 12.9)$ \\
Starch (\%) & $0.2(0 ; 0.5)$ & $0.3(0 ; 0.5)$ \\
NFC (\%) & $13.2(10 ; 16.4)$ & $19.8(17.9 ; 21.6)$ \\
Estimated fructan (\%) & $0.8(0.7 ; 1)$ & $4(2.2 ; 5.9)$ \\
NSC (\%) & $6.5(4.5 ; 8.5)$ & $15.7(12.7 ; 18.6)$ \\
\hline
\end{tabular}

Dry Matter (DM) (\%), Digestible Energy (DE) (Mcal/Kg), Crude Protein (\%), Estimated Lysine (\%), Acid Detergent Fiber (ADF) (\%), Neutral Detergent Fiber (NDF) (\%), WSC (Water Sol. Carbs.) (\%), ESC (Simple Sugars) (\%), Starch (\%), Non- Fiber Carb. (NFC), Non-structural carbohydrates (NSC) (\%). Values are shown as mean (95\% confidence interval).

the grass for ponies and horses also differed on crude protein, water soluble carbohydrates, simple sugars, non-fiber-carbohydrates, estimated fructan and non-structural carbohydrates.

\section{MicroRNA profiles}

From the 340 miRNAs analyzed, several were found to be in different relative quantity between groups $(\mathrm{p}<0.05)$. There were 13 miRNAs differently expressed between insulin resistant and insulin sensitive horses (Figure 3), 15 differently expressed between insulin resistant and insulin sensitive ponies (Figure 4,17 differently expressed between horses and ponies (Figure 5), and 14 differently expressed between insulin resistant and insulin sensitive animals (Figure 6), horses and ponies combined, with 4 of these miRNAs already noted when comparing horses versus ponies. Therefore, 10 miRNAs were exclusively quantitatively different between insulin resistant and insulin sensitive animals, horses and ponies combined (Figure 6). In the horse groups, 3 miRNAs were expressed in one group only, IR, and 1 miRNA was repeated from our previous study, mir-140-3p in horses (da Costa Santos et al., 2018). Additionally, DIANA TOOLS pathway analysis indicated that many of these significant miRNAs have already been associated with type 2 diabetes, metabolic syndrome, hyperinsulinism, hyperglycemia, obesity, or insulin resistance in either humans (Table 6) or mouse (Table 7).

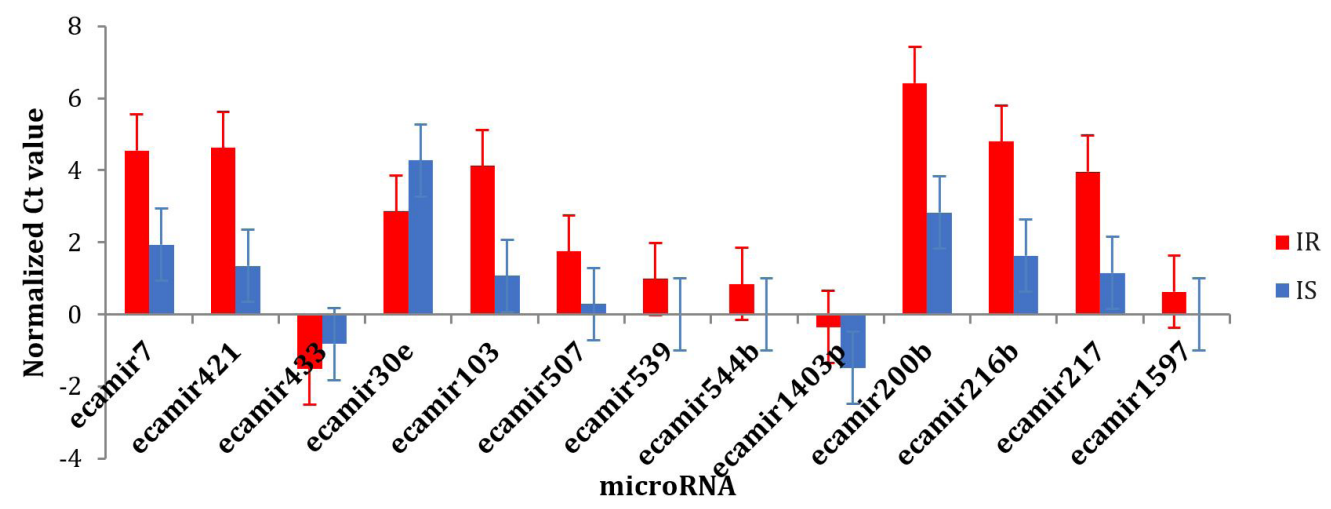

Figure 3. Delta Ct means and SE of significantly different miRNAs between groups: insulin sensitive (IS, $n=10$ ) and insulin resistant ( $I R, n=2)$ horses. 


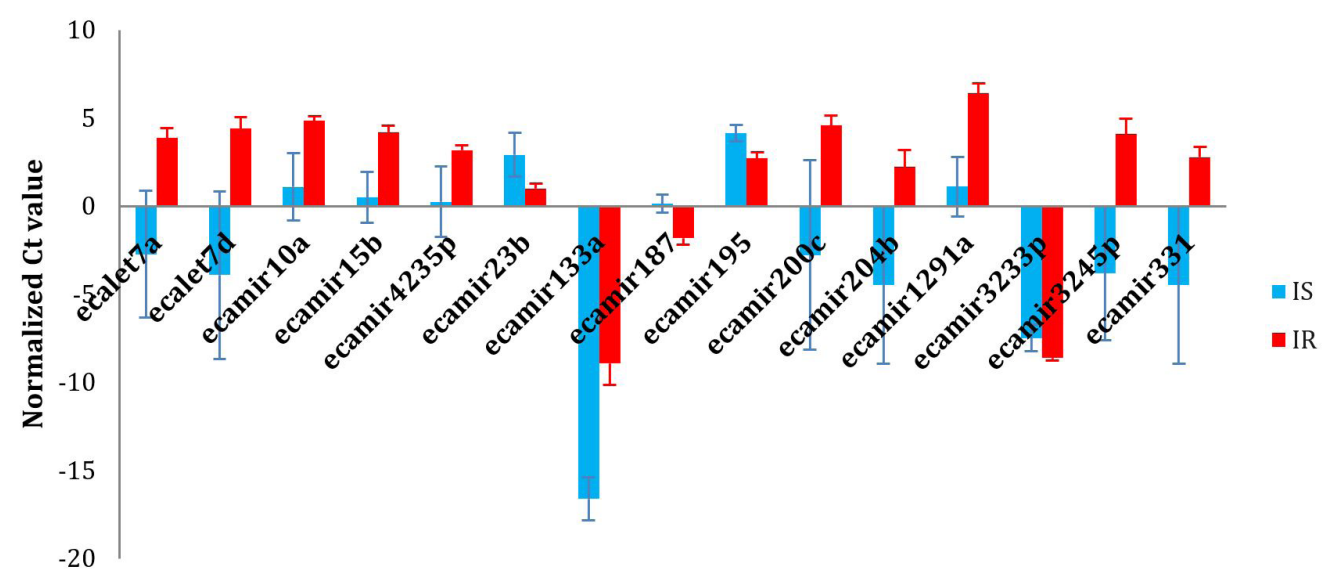

microRNA

Figure 4. Delta Ct values of significantly different miRNAs between groups: insulin sensitive (IS, $\mathrm{n}=4$ ) and insulin resistant $(\mathrm{IR}, \mathrm{n}=8)$ ponies.

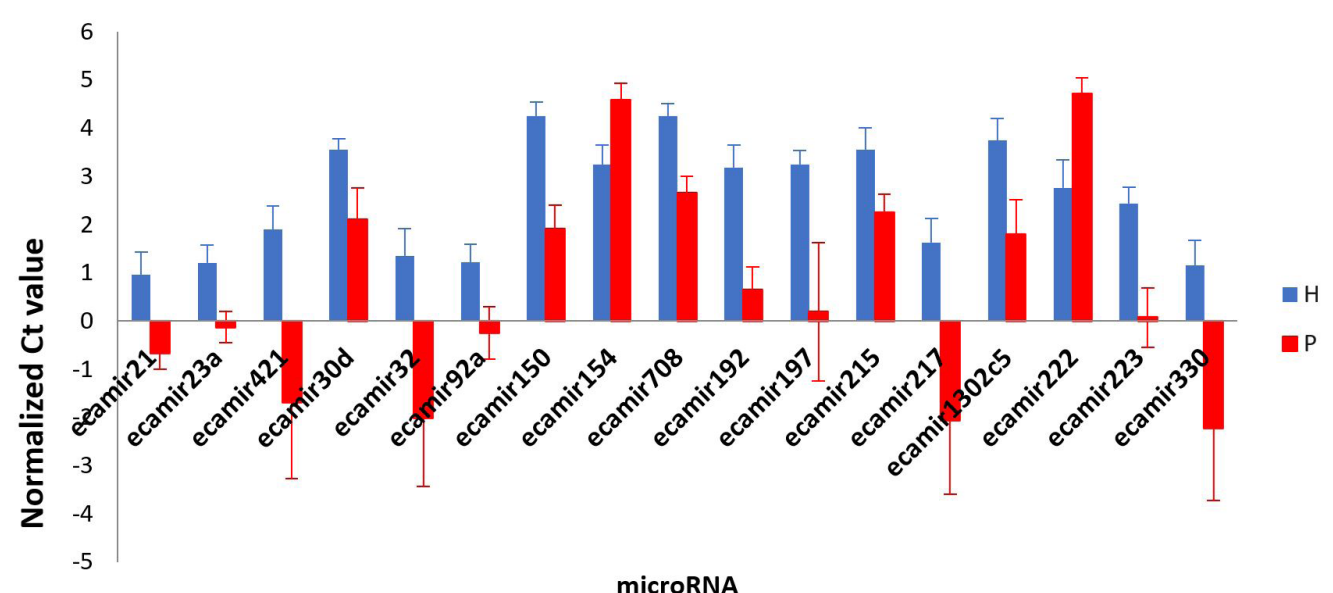

Figure 5. Delta Ct values of significantly different miRNAs between groups: combined horses versus $(\mathrm{H})$ combined ponies (P).

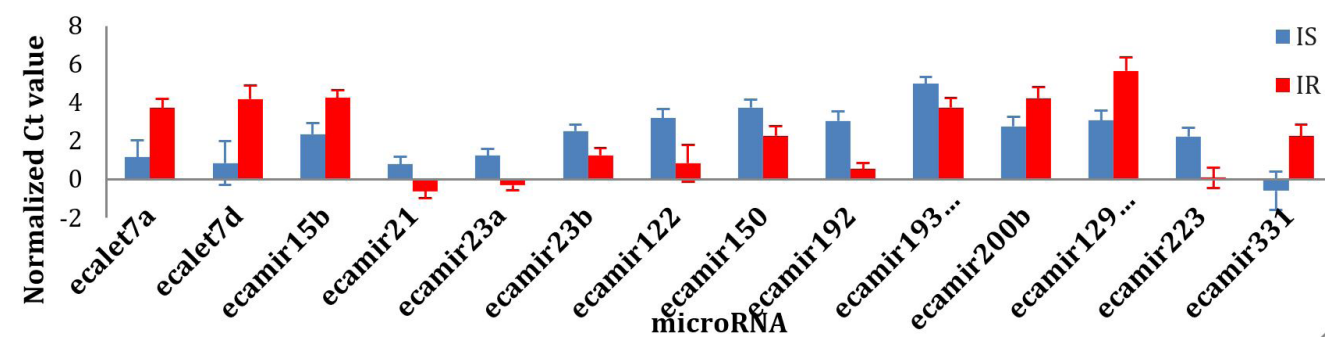

Figure 6. Delta Ct values of significantly different miRNAs between groups: combined insulin resistant animals (IR, $n=10$ ) versus combined insulin sensitive animals (IS, $n=14$ ).

\section{MicroRNAs significantly different between insulin resistant and insulin sensitive horses}

From the 13 miRNAs quantitatively different between groups, 8 were higher in the insulin resistant group: eca-mir-200b, eca-mir-421, eca-mir-216b, eca-mir-103, eca-mir-217, eca-mir-7, eca-mir-507, and eca-mir-140-3p; 3 were expressed in insulin resistant group only: eca-mir-539, eca-mir-544b, and eca-mir-1597; and 2 were higher in insulin sensitive group: eca-mir-433 and eca-mir-30e (Figure 3). 
Table 6. Significantly different microRNA and their associated diseases, in humans. DIANNA Pathway analysis.

\begin{tabular}{|c|c|c|c|c|c|c|}
\hline $\begin{array}{c}\text { microRNAs in } \\
\text { Horses }\end{array}$ & T2D & MetS & Hyperins & Hyperglyc & Obesity & $\begin{array}{c}\text { Ins } \\
\text { Resist }\end{array}$ \\
\hline mir-200b & Yes & Yes & Yes & Yes & No & Yes \\
\hline mir-421 & Yes & No & Yes & Yes & No & No \\
\hline mir-216b & No & No & No & No & No & No \\
\hline mir-103 & No & No & No & No & No & No \\
\hline mir-217 & No & No & No & No & No & No \\
\hline mir-7 & No & No & No & No & No & No \\
\hline mir-507 & No & No & No & No & Yes & No \\
\hline mir-140-3p & Yes & No & No & No & Yes & No \\
\hline mir-539 & Yes & No & No & No & Yes & No \\
\hline mir-544b & No & No & No & No & No & No \\
\hline mir-1597 & No & No & No & No & No & No \\
\hline mir-433 & Yes & No & No & No & Yes & No \\
\hline mir-30e & Yes & Yes & Yes & Yes & Yes & No \\
\hline $\begin{array}{l}\text { microRNAs in } \\
\text { Ponies }\end{array}$ & T2D & MetS & Hyperins & Hyperglyc & Obesity & $\begin{array}{c}\text { Ins } \\
\text { Resist }\end{array}$ \\
\hline mir-1291a & No & No & No & No & No & No \\
\hline mir-15b & Yes & Yes & No & Yes & Yes & No \\
\hline mir-133a & Yes & No & Yes & Yes & No & No \\
\hline mir-10a & Yes & Yes & No & No & Yes & No \\
\hline mir-324-5p & Yes & No & Yes & Yes & No & No \\
\hline let7a & Yes & No & No & No & Yes & No \\
\hline let7d & Yes & No & No & No & Yes & Yes \\
\hline mir-187 & No & No & No & No & No & No \\
\hline mir-331 & No & Yes & No & No & No & No \\
\hline mir-423-5p & Yes & No & Yes & Yes & No & No \\
\hline mir-200c & Yes & Yes & Yes & Yes & No & Yes \\
\hline mir-323-3p & Yes & No & No & No & Yes & No \\
\hline mir-204b & No & No & No & No & No & No \\
\hline mir-23b & Yes & No & No & No & Yes & Yes \\
\hline mir-195 & No & No & No & No & No & No \\
\hline $\begin{array}{c}\text { microRNAs } \\
\text { Combined }\end{array}$ & T2D & MetS & Hyperins & Hyperglyc & Obesity & $\begin{array}{c}\text { Ins } \\
\text { Resist }\end{array}$ \\
\hline let7d & Yes & No & No & No & Yes & Yes \\
\hline mir-331 & No & Yes & No & No & No & No \\
\hline mir-1291a & No & No & No & No & No & No \\
\hline let7a & Yes & No & No & No & Yes & No \\
\hline mir-15b & Yes & Yes & No & Yes & Yes & No \\
\hline mir-200b & Yes & Yes & Yes & Yes & No & Yes \\
\hline mir-193a-5p & Yes & No & Yes & Yes & Yes & No \\
\hline mir-23b & Yes & No & No & No & Yes & Yes \\
\hline mir-150 & No & No & No & No & Yes & No \\
\hline mir-122 & No & No & No & No & No & No \\
\hline
\end{tabular}

Type 2 diabetes (T2D), metabolic syndrome(MetS), hyperinsulinism (Hyperins), hyperglycemia(Hyperglyc), insulin resistance(Ins Resist). 
Table 7. Significantly different microRNA and their associated diseases, in mouse. DIANNA Pathway analysis.

\begin{tabular}{|c|c|c|c|c|c|c|}
\hline $\begin{array}{c}\text { microRNAs in } \\
\text { Horses }\end{array}$ & T2D & MetS & Hyperins & Hyperglyc & Obesity & Ins Resist \\
\hline mir-200b & Yes & No & Yes & Yes & No & Yes \\
\hline mir-421 & Yes & No & Yes & Yes & No & No \\
\hline mir-216b & No & No & No & No & No & No \\
\hline mir-103 & No & No & No & No & No & No \\
\hline mir-217 & No & No & No & No & No & No \\
\hline mir-7 & No & No & No & No & No & No \\
\hline mir-507 & No & No & No & No & No & No \\
\hline mir-140-3p & No & No & No & No & No & No \\
\hline mir-539 & Yes & No & No & No & Yes & No \\
\hline mir-544b & No & No & No & No & No & No \\
\hline mir-1597 & No & No & No & No & No & No \\
\hline mir-433 & No & No & No & No & No & No \\
\hline mir-30e & Yes & Yes & Yes & Yes & Yes & No \\
\hline $\begin{array}{l}\text { microRNAs in } \\
\text { Ponies }\end{array}$ & T2D & MetS & Hyperins & Hyperglyc & Obesity & Ins Resist \\
\hline mir-1291a & No & No & No & No & No & No \\
\hline mir-15b & Yes & Yes & No & Yes & Yes & No \\
\hline mir-133a & Yes & No & Yes & Yes & No & No \\
\hline mir-10a & Yes & Yes & No & No & Yes & No \\
\hline mir-324-5p & Yes & No & Yes & Yes & No & No \\
\hline let7a & Yes & No & No & No & Yes & Yes \\
\hline let7d & Yes & No & No & No & Yes & Yes \\
\hline mir-187 & No & No & No & No & No & No \\
\hline mir-331 & No & Yes & No & No & No & No \\
\hline mir-423-5p & Yes & No & Yes & Yes & No & No \\
\hline mir-200c & Yes & Yes & Yes & Yes & No & Yes \\
\hline mir-323-3p & Yes & No & No & No & Yes & No \\
\hline mir-204b & No & No & No & No & No & No \\
\hline mir-23b & Yes & No & No & No & Yes & Yes \\
\hline mir-195 & No & No & No & No & No & No \\
\hline $\begin{array}{c}\text { microRNAs } \\
\text { Combined }\end{array}$ & T2D & MetS & Hyperins & Hyperglyc & Obesity & Ins Resist \\
\hline let7d & Yes & No & No & No & Yes & Yes \\
\hline mir-331 & No & Yes & No & No & No & No \\
\hline mir-1291a & No & No & No & No & No & No \\
\hline let7a & Yes & No & No & No & Yes & Yes \\
\hline mir-15b & Yes & Yes & No & Yes & Yes & No \\
\hline mir-200b & Yes & No & Yes & Yes & No & Yes \\
\hline mir-193a-5p & No & No & No & No & No & No \\
\hline mir-23b & Yes & No & No & No & Yes & Yes \\
\hline mir-150 & No & No & No & No & Yes & No \\
\hline mir-122 & No & No & No & No & Yes & No \\
\hline
\end{tabular}

Type 2 diabetes (T2D), metabolic syndrome (MetS), hyperinsulinism (Hyperins), hyperglycemia (Hyperglyc), insulin resistance (Ins Resist). 


\section{MiRNAs significantly different between insulin resistant and insulin sensitive ponies}

From the 15 miRNAs quantitatively different between groups, 4 were higher in the insulin sensitive group: eca-mir-187, eca-mir-323-3p, eca-mir-23b, eca-mir-195; and 11 higher in the insulin resistant: eca-mir-1291a, eca-mir-15b, eca-mir-133a, eca-mir-10a, eca-mir-324-5p, eca-let-7a, ecalet-7d, eca-mir-331, eca-mir-423-5p, eca-mir-200c, eca-mir-204b (Figure 4).

\section{MicroRNAs significantly different between ponies and horses}

Furthermore, we compared circulating miRNA profiles between ponies and horses, combining animals regardless of whether they were insulin resistant or insulin sensitive. There were $17 \mathrm{miRNAs}$ quantitatively different between groups, from which 15 were higher in horses: eca-mir-150, eca-mir-192, eca-mir-708, ec-amir-223, eca-mir-21, eca-mir-23a, eca-mir-1302c5, eca-mir-217, eca-mir-215, eca-mir-92a, eca-mir-32, eca-mir-421, eca-mir-330, eca-mir-30d, eca-mir-197; and 2 higher in ponies: eca-mir-222, eca-mir-154 (Figure 5).

\section{MicroRNAs significantly different insulin resistant and insulin sensitive animals}

Finally, we compared insulin resistant with insulin sensitive animals, combining groups independently of being horses or ponies, there were 14 miRNAs differently expressed between groups. However, 4 of these miRNAs overlapped the ones found significant between horses and ponies: eca-mir-192, eca-mir-223, eca-mir-23a, eca-mir-21. From the 10 remaining miRNAs quantitatively different between groups, 6 were higher in the insulin resistant group: eca-let-7d, eca-mir-331, eca-mir-1291a, eca-let-7a, eca-mir-15b, eca-mir-200b; and 4 higher in the insulin sensitive group: eca-mir-193a-5p, eca-mir-23b, eca-mir-150, eca-mir-122 (Figure 6).

\section{Discussion}

In the current study, a total of 13 miRNAs were found differently expressed between insulin resistant and insulin sensitive horses. Our preliminary study (da Costa Santos et al., 2018) found 6 circulating miRNAs that were expressed only in insulin sensitive mares, 5 miRNAs that were found in lower quantity in insulin resistant mares, and 3 miRNAs that were found in higher quantity in insulin resistant mares, totaling 14 miRNAs differently expressed between groups in horses. In addition, the miRNA profiles were different between the preliminary and current studies. The different results between studies are likely due to seasonal variations during sample collections between studies in addition to sample size differences. To test this hypothesis, more studies investigating associations in circulating miRNAs in horses and seasonal and nutritional changes would be necessary.

Although both studies used the same population of horses, the samples were not collected in the same seasonal period and included different animals from the herd. In the preliminary study, samples for horses were collected in the spring and had higher levels of NSC (average of $16.9 \% \mathrm{DM}$ ), whereas the current samples were collected in the winter, with average NSC of $6.5 \%$ DM. Ponies had average NSC of 15.7\% DM (Table 1). Seasonal changes can induce variations in the nutritional content of the pasture, especially in the way that carbohydrates from grass are stored (Metson et al., 1979; Longland \& Byrd, 2006). Changes in diet have been shown to affect the levels of miRNAs (Becker \& Lockwood, 2013; Witwer, 2012). Pastures with high NSC content can predispose horses to many diseases including insulin resistance (Bailey et al., 2008; McFarlane et al., 2011; Donaldson et al. 2005).

The pilot investigation had a smaller sample size, with only 6 horses ( 3 insulin resistant and 3 insulin sensitive). The current study had a larger sample size of 12 horses and had an uneven distribution of insulin resistant versus sensitive equids ( 2 insulin resistant and 10 insulin sensitive horses). In contrast to our pilot study, there was no variation in body condition between insulin resistant and insulin sensitive horses. The body condition score had a smaller range in insulin resistant horses (between 7 and $8, n=2$ ) whereas the range was larger in insulin sensitive horses (between 5.5 and $8, n=10$ ). However, the non-significance in this parameter may be due to the small number of animals in the insulin resistant group $(\mathrm{n}=2)$.

In contrast to the previous study, the current group of animals included a population of ponies for circulating miRNA profiling. Insulin sensitive ponies and horses had similar AIRg, area under 
the insulin curves, or basal insulin. The same applied for insulin resistant ponies versus insulin resistant horses, demonstrating homogeneity between insulin resistant groups (horses and ponies). Furthermore, 15 miRNAs were differently expressed between insulin resistant and insulin sensitive ponies. There is no current data available to compare our results with, but studies using humans and mice have shown many of the found miRNAs to be relevant in insulin resistance and associated conditions.

Finally, 10 miRNAs were differently expressed between insulin resistant and insulin sensitive animals (horses and ponies combined) indicating potential similarity in the mechanisms of insulin resistance in Thoroughbred/ Thoroughbred-cross horses and Welsh/Dartmoor ponies.

Despite the differences in the results of the studies, both investigations were able to show differences in miRNA profiles between insulin resistant and insulin sensitive animals. These differences are potentially relevant to equine insulin resistance based on research conducted in humans and mice.

\section{Possible breed associated differences in circulating microRNA profiles}

In addition to comparing circulating miRNA profiles between insulin resistant and insulin sensitive animals, this study also compared circulating miRNA profiles between animal breeds: horses versus ponies. Our results found 17 differently expressed miRNAs between these groups, supporting circulating miRNAs as potential tools to differentiate specific breed types, which has already been suggested (Pacholewska et al., 2016).

Only miR-122 and miR-154 were found in higher quantity in ponies compared to horses. The remaining 15 miRNAs were in higher quantity in horses compared to ponies. It is recognized that there are breed-related differences in glucose and insulin dynamics in equids, and that ponies and certain horse breeds, such as Morgans and Paso Finos, are more commonly affected by insulin resistance and endocrinopathic laminitis (Bamford et al., 2014; Jeffcott et al., 1986). Breed-related differences in the insulin responses of horses and ponies seem to be independent of obesity (Bamford et al., 2014). Therefore, the difference in circulating miRNA profiles between these breed groups may also be associated with their predisposition to insulin resistance and associated conditions. As described in more detail below, miR-122 has been related to cholesterol levels (Esau et al., 2006).

In this study, ponies were more prone to be insulin resistant whereas horses were more prone to be insulin sensitive. Therefore, the metabolic differences between groups (ponies versus horses) may have interfered in the results. For future studies, it would be recommended to pair more metabolically homogeneous groups and to explore the metabolic differences between breeds in association to their circulating miRNA profiles.

\section{Insulin sensitivity testing}

\section{Influences of the non-structural carbohydrate content in the pastures}

The combination of genetic predisposition, in addition to nutritional factors, such as high fractions of non-structural carbohydrate (NSC), seem to have impacted the metabolic state of the animals in this study. Horses tended to be more insulin sensitive and ponies more insulin resistant. Additionally, the NCS content in the diet for ponies was higher than the NCS content in the diet for horses. High NSC content (which includes simple sugars, starch, and fructans) in pasture grasses plays an important role in the relationship between insulin resistance and laminitis. Excessive NSC consumption decreases insulin sensitivity while leading to altered bacterial flora in the large intestine of horses and increased production of compounds that have the potential to cause peripheral vasoconstriction, playing an important role in the pathogenesis of laminitis (Bailey et al., 2002). Most of the horses (10 out of 12) were diagnosed as insulin sensitive, and most ponies ( 9 out of 12 ) were diagnosed as insulin resistant.

It is recommended for horses and ponies with insulin resistance to be offered feed with less than $10 \%$ to $12 \%$ NSC (which includes simple sugars, fructans, and starches) of dry matter (Geor, 2010, 2013). The horses in this study were offered feed with the NSC lower (4.5 to 8\%) than this recommendation, whereas the ponies had higher NSC content (12.9 to 19.9\%). The content of NSC in the feed can have a significant impact on postprandial insulin response and digestive 
fermentation, resulting in chronic metabolic disorders associated with high glycemic and insulinemic responses and laminitis (Longland \& Byrd, 2006; Lindåse et al., 2018; Kronfeld \& Harris, 2003; Garner et al., 1977). For future studies, it would be recommended to equally control for feed content factors for both breeds by moving groups to dry lots at least one month before test sampling and offer them the same diet.

\section{The diagnosis of insulin resistant animals: Minimal model parameters}

The main factors for diagnosing animals in this study were the estimated area under the curve for the FSGIT tests for insulin and basal insulin concentration. Insulin resistant animals have higher areas under the insulin curve as a result of not being able to mediate glucose uptake as efficiently as an insulin sensitive animal.

In our pilot study, the area under the curve for insulin for insulin resistant horses had a mean of 24494 (95\% confidence interval: 22457;26,717) $\mu \mathrm{IU} / \mathrm{mL} \times$ min, while in the current study, the mean for insulin resistant horses was 26190 (95\% confidence interval: 17074; 40174) $\mu \mathrm{IU} / \mathrm{mL} \times$ min and 24510 (95\% confidence interval: 21270; 28244) $\mu \mathrm{IU} / \mathrm{mL} \times \min$ for insulin resistant ponies. The area under the insulin curve for insulin sensitive horses in our pilot study had a mean of 6758 ( $95 \%$ confidence interval: 4653; 9816) $\mu \mathrm{IU} / \mathrm{mL} \times$ min, while in the current study, the mean was 5685 (95\% confidence interval: 4987; 6480) $\mu \mathrm{IU} / \mathrm{mL} \times$ min for insulin sensitive horses and 8192 (95\% confidence interval: 5855;11463) $\mu \mathrm{IU} / \mathrm{mL} \times$ min for insulin sensitive ponies. These results confirm that higher concentrations of insulin are required to maintain normal levels circulating glucose, as can be noticed in the values for basal glucose and estimated area under the curve for glucose (Table 3b). Based on their area under the curve for both glucose and insulin in this study, insulin resistant horses and ponies indicated a hyperinsulinemic-normoglycemic physiological state.

\section{Potential miRNA targets in insulin resistance for horses}

Our results showed that horses with insulin resistance had higher levels of circulating miR200b. It has been suggested that decreased expression of miR-200 family miRNAs (miR-200s), including miR-200a, miR-200b, and miR-200c, contribute to hepatic insulin resistance (Dou et al., 2013). Hepatic insulin resistance refers to impaired suppression of glucose production by insulin in hepatocytes and been suggested as an underlying cause of metabolic syndrome in humans being also linked to hyperglycemia, dyslipidemia and increased inflammatory factors (Meshkani \& Adeli, 2009). In addition, decreased levels of miR-200s have been observed during elevated serum concentration of interleukin-6 (IL-6). The administration of IL-6 has been shown to induce insulin resistance through down-regulation of miR-200s resulting in impaired activation of the PI3K/AKT pathway and synthesis of glycogen in mice (Dou et al., 2013). Adipose tissue is one of the main sources of inflammatory mediators including IL-6, and elevated IL-6 levels have been reported in obese humans (Eder et al., 2009). Therefore, it is possible that the higher level of circulating miR-200b in insulin resistant horses could be associated with an increased body condition score and being overweight. However, because of the small number of animals in this group, it is not possible to confirm this hypothesis. Additionally, the expression levels of circulating miR-200b-3p has been shown to be higher in horses with acute laminitis and decreasing after routine laminitis treatment (Lecchi et al., 2018). Insulin resistant ponies we used in the study had higher levels of Mir-200b and have history of laminitis. Both insulin resistance and incidence of laminitis are traits for equine metabolic syndrome and therefore, miR-200b may have great potential as biomarker for this metabolic condition.

MiR-421-3p has been observed to be upregulated in the liver of mice fed a high fat diet and causally linked to the development of hepatic insulin resistance. Additionally, in silico target analysis identified miR-421-3p as having putative binding sites for the 3'UTRs of insulin receptor (INSR) and insulin receptor substrate 1 (IRS-1) genes (Yang et al., 2016). Although there was no significant difference in body weight and BCS between insulin resistant and insulin sensitive horses, it is possible that impairment in the fat metabolism of insulin resistant animals caused differences in circulating levels of miR-421 between groups. Future studies including the lipid profile of insulin resistant in contrast to insulin sensitive animals can be helpful addressing this possibility. 
It has been shown that miR-103 targets caveolin-1, a critical regulator of the insulin receptor, and expression of miR-103 is upregulated in the liver and fat tissues of obese mice. Increased activity of miR-103 can induce impaired glucose homeostasis, and silencing miR-103 is concomitant with stabilization of the insulin receptor, enhanced insulin signaling, decreased adipocyte size and enhanced insulin-stimulated glucose uptake (Trajkovski et al., 2011). If similar to mice, the higher concentration of circulating miR-103 in insulin resistant horses found in this study may be due to the expected increased concentration of miR-103 in the liver and fat tissues.

Increased concentration of serum miR-217 has been associated with the development of proteinuria in type 2 diabetes human patients and may be involved in the development of diabetic kidney disease by promoting chronic inflammation, renal fibrosis, and angiogenesis in humans (Shao et al., 2017). Additionally, it has been proposed that blocking miR-217 might improve insulin resistance under high glucose diet in mice (Sun et al., 2017). Furthermore, phosphatase and angiotensin homologue (PTEN) is a tumor suppressor that serves as a negative regulator of PI3K/PTEN/Akt signaling pathway and is downregulated by miR-217. The PI3K/PTEN/ Akt signaling cascades have important effects on glucose uptake via translocation of GLUT-4, and overexpression of PTEN inhibits GLUT-4 translocation and glucose transport (Li et al. 2017; Kato et al., 2009; Nakashima et al., 2000). In our current study, miR-217 was found in higher quantity in insulin resistant animals, as expected for humans with type 2 diabetes. The increase in circulating miR-217 may be given to an attempt of the organism to increase glucose uptake by cells and alleviate the hyperglycemia stress associated with insulin resistance. However, the actual role of miR-214 in equine metabolism during the state of insulin resistance remains unclear.

In mouse muscle cells, overexpression of miR-7 was shown to downregulate expression of IRS-1 and to inhibit insulin-stimulated Akt phosphorylation and glucose uptake, inducing insulin resistance (Li et al. 2011). Likewise, our study found that miR-7 was in higher quantity in insulin resistant compared to insulin sensitive horses.

In contrast to our previous study (da Costa Santos et al., 2018), miR-140-3p was found to be in higher quantity in insulin resistant horses in this study. Downregulation of miR-140-3p has been associated with calorie restriction (Pando et al., 2012), while its upregulation has been associated with diabetes, specifically type 2 diabetes (Collares et al., 2013). The difference in the miR-140-3p levels in this and our previous study may be due to a combination of seasonal variations, since our first study performed the FSIGT test in May versus January for our current study, and animal composition, since the body condition score between insulin sensitive horses in both studies differs from each other. However, more studies are necessary to investigate the source of variation and the relationship between circulating miR-140-3p levels and equine insulin resistance. Additionally, mir-140, same family of mir-140-3p, is believed to play a role in the link between adipose tissue dysfunction and the development of obesity-associated disorders such as type 2 diabetes (Wang et al., 2016).

Expression of miR-30e has been found to be higher in abdominal subcutaneous adipose tissue in normal glucose tolerance compared to newly diagnosed type 2 diabetes humans, being considered to play a role in the link between adipose tissue dysfunction and the development of obesity associated disorders including type 2 diabetes (Klöting et al., 2009). Additionally, downregulation of miR-30e has been reported during high fat diet induced obesity in mice (Chartoumpekis et al., 2012), and in human patients with type 2 diabetes (Zhu \& Leung, 2015; Collares et al., 2013). Similarly, our insulin resistant horses had lower levels of miR-30e. No relevant data for insulin resistance and associated conditions was found for miR-216b, miR-507, miR-539, miR-544b, miR-1597, and miR433 in our review.

\section{Potential miRNA targets in insulin resistance for ponies}

MiR-15b has been shown as a potential predictive biomarker in obesity, being higher in obese individuals when compared to controls, diabetic, and obese diabetic individuals (Pescador et al., 2013). Furthermore, miR-15b has been reported to target the INSR, and overexpression of miR-15b impairs the insulin signaling cascade, as well as insulin stimulated glycogen storage in hepatocytes, being linked to the pathogenesis of hepatic insulin resistance in saturated fatty acid induced obesity (Yang et al., 2015). Similar to these studies, miR-15b was higher in the insulin resistant 
group, and these horses they were at a body condition above 6.5, which has been associated with metabolic syndrome (Kahn \& Flier, 2000).

MiR-133a is expressed in both brown adipose tissue and white adipose tissue, and regulates adipocyte browning in vivo (Liu et al., 2013). MiR-133a has been reported as being down regulated in liver of db/db mice compared with control (Nakanishi et al., 2009). However, in our study, insulin resistant ponies were found to have higher levels of circulating miR-133a, which may be different from organ levels.

MiR-10a has been reported as being dysregulated in human type 2 diabetic muscles (Gallagher et al., 2010; Chen et al., 2012; Massart et al., 2016). Additionally, miR-10a overexpression improved kidney damage of diabetes, while diabetes induced the decrease of miR-10a level in the kidney in mice (Shan et al., 2016). Our results showed that levels of circulating miR-10a were higher in insulin resistant animals. However, the physiological impacts of high levels of circulating miR-10a in equids is still uncertain.

MiR-331 has been shown to be involved in glucose metabolism (Calvier et al., 2017), and reported as being dysregulated in human type 2 diabetic muscles (Massart et al., 2016; Shan et al., 2016; Calvier et al., 2017). Mir-331 was found to be higher in insulin resistant ponies in the current investigation.

A study found inverse associations of miR-423-5p with obesity measures and markers of inflammation (Tijsen et al., 2010), and it has been suggested as a potential biomarker for risk estimation and classification of morbidly obese patients (Pescador et al., 2013; Ortega et al., 2013). Lastly, miR-423-5p has also been reported to be differentially expressed in subjects with prediabetes and type 2 diabetes patients compared to control subjects. The same study also found that miR-423-5p had sex-specific associations with prediabetes or diabetes (Prabu et al., 2015). In our study, higher levels of circulating miR-423-5p were associated with insulin resistance in ponies in accordance with the previous study in humans (Kameswaran et al., 2014). Mir-187 has been reported to be expressed in higher levels in pancreatic islets of human diabetic versus non-diabetic donors (Kameswaran et al., 2014; Locke et al., 2014). In the current study, miR-187 was found in lower circulating levels in insulin resistant versus insulin sensitive horses, indicating that circulating levels of miRNAs may be different from their tissue levels.

Our results found that insulin resistant ponies had higher concentration of circulating let-7a and let-7b. It has been suggested that let-7 family miRNAs, including let-7a and let-7d, represents a potential therapeutic target for the treatment of type 2 diabetes. It has been demonstrated that let-7 regulates multiple aspects of glucose metabolism. Global and pancreas-specific overexpression of let-7 in mice results in impaired glucose tolerance and reduced glucose-induced pancreatic insulin secretion. In addition, global knockdown of the let-7 family can prevent and treat impaired glucose tolerance in mice with diet induced obesity (Frost \& Olson, 2011; Williams \& Mitchell, 2012). Furthermore, it has been shown that let-7a and let-7d are direct translational repressors of the IL-13 gene and their expression increases in skeletal muscle from type 2 diabetes patients (Jiang et al., 2013). Let-7 is also involved in the regulation of FAM174A gene (Karagkouni et al., 2018). This gene has been found to be near significant genetic markers for elevated insulin values and increased frequency of laminitis in Arabian horses. Therefore, FAM174A has been proposed to have an important role in the risk for equine metabolic syndrome (Lewis et al., 2017).

Insulin resistant ponies had higher levels of circulating mir-200c, miR-200s family, compared to insulin sensitive ponies. Similar to horses, this difference may be related to hepatic insulin resistance and excess adipose tissue (Dou et al., 2013), and laminitis (Lecchi et al., 2018) in ponies. Additionally, miR-324-5p levels have been found to be increased in the serum of type 1 diabetic children (Erener et al., 2017), which were also elevated in insulin resistant ponies compared to sensitive group, indicating a possible link between this miRNA and type 1 and type 2 diabetes.

Although there were higher levels of miR-195 were found in the serum of insulin sensitive animals, studies have shown that miR-195 is upregulated in the liver of hyperglycemic mice (Herrera et al., 2010). Levels of miR-195 have been shown to be upregulated in the liver, but not in the skeletal muscle, of diet-induced obese mice. Additionally, miR-195 can suppress INSR buy targeting INSR 3'UTR directly. It can also be induced by saturated fatty acid palmitate, being causally involved in the development of insulin resistance induced by saturated fatty acid (Herrera et al., 2010; Yang et al., 2014). Because our study focused on circulating miRNAs, it is not possible to know whether levels of miR-195 were increased in the liver of insulin resistant ponies or not. More 
studies are necessary to evaluate the association between the levels of miR-195 in the circulation and in the liver of horses. No relevant data for insulin resistance and associated conditions was found for miR-1291a, miR-323-3p, miR-204b, miR-23b, and miR-195 in our review.

\section{Insulin resistant versus insulin sensitive animals combined}

Finally, from the 10 miRNAs differently expressed between insulin resistant horses and ponies combined versus insulin sensitive horses and ponies combined, 7 miRNAs were shown to be differently expressed in either the insulin resistant versus insulin sensitive horses' analysis: miR-200b; or the insulin resistant versus insulin sensitive ponies' analysis: let-7a, let-7d, miR-23b, miR-1291a, miR-15b, and miR-331. From the remaining 3 miRNAs, miR-150 has been suggested to participate in the regulation of insulin signaling, with two potential targets being proposed for mR-150: CBL, which specifically targets activated protein tyrosine kinases and regulates their signaling, and GLUT-4. MiR-150 has been shown to be upregulated in adipose and liver tissues of type 2 diabetic mice (Karolina et al., 2011). In contrast, it has been reported that miR-150 modulates adipose tissue function, and that miR-150 deficiency significantly impairs insulin signaling pathway in mice under obese stress (Ying et al., 2016). Furthermore, our study indicated that insulin sensitive animals had higher levels of circulating miR-150. However, more studies are necessary to address the physiological impact of miR-150 in equine health.

Inhibition in a diet-induced obesity mouse model of miR-122 has been reported to decrease plasma cholesterol levels and to improve liver steatosis, fat in the liver (Esau et al., 2006). However, more studies are required to evaluate the physiological impact of decreased circulating levels of miR-122 in insulin resistant equids. Additionally, miR-193-5p has been reported to regulate insulinlike growth factor 2 (IGF-2) and to be an active angiogenic factor in diabetic cardiomyopathy, a condition that makes it hard for the heart to deliver blood to the body, in rats (Yi et al., 2017). Furthermore, expression of miR-193 in the liver has been reported to have a linear relationship with plasma triacylglycerol levels Herrera et al., 2010). Insulin resistant animals had lower levels of circulating miR-193a-5p. Even though it may be related to changes in blood pressure and lipid profile in our animals, the actual impact of this miRNA in horses remains to be clarified.

\section{Relevant microRNAs for equine insulin resistance}

A significant quantity of miRNAs described here have shown importance to insulin resistance and related conditions in other species (mainly humans and mice) based on the information found during our miRNA literature reviews. However, our current data does not allow us to conclude on the miRNA pathways related to insulin resistance and related conditions in equids.

Our investigation of miRNAs associated with equine insulin resistance also included database analysis: (1) DIANNA TOOL mirPath v.3 for miRNA pathway analysis and miRNA-disease associations [22]; (2) TarBase v.8 for miRNA-gene interactions (Karagkouni et al., 2018); and (3) DisGeNET RDF v4.0 for genes and variants associated with human disease (Piñero et al., 2015, 2017). This data altogether allows the selection of the most probable key regulators associated with insulin resistance in horses.

The DIANNA TOOL mirPath v.3 analysis indicated that at least 12 of all the 33 circulating miRNAs found in different relative quantities in this study have been reported to be linked to at least 3 conditions associated to insulin resistance in either humans or mice: miR-200b, miR-193a-5p, let7, miR-10a, miR-133a, miR-15b, miR-200b, miR-23b, miR-30e, miR-324-5p, miR-421, and miR-423-5p.

In addition, 15 of these 33 miRNAs have been reported to be linked to genes associated with insulin resistance in humans (Karagkouni et al., 2018). It includes 8 of the top 10 scored gene associations for this disease (Piñero et al., 2015, 2017: Peroxisome proliferator activated receptor gamma (PPARG): miR-324; Tumor necrosis fator (TNF): miR-1291; Adrenoceptor beta 2 (ADRB2): let-7 and miR-23b; Insulin receptor (INSR): miR-30e, miR-10a, miR-23b, miR-195, let-7, and miR-122; Glucokinase (GCK): miR-331; Protein kinase AMP-activated catalytic subunit alpha 1 (PRKAA1): miR-217, miR-421, miR-30e, miR-103a, miR-216b, let-7, miR-10a, miR-23b, miR-133a, and miR-122; Insulin receptor substrate 1(IRS1): miR-103a and miR-195; and Insulin (INS): miR-200b. Additionally, 7 of these miRNAs are associated with at least 2 of these genes: let-7, miR-103a, miR-10a, miR-122, miR-195, miR-23b, and miR-30e.

Finally, 8 miRNAs were both linked to (1) at least 3 conditions associated with insulin resistance in either humans or mice and to (2) at least one of the genes associated with insulin resistance 
in humans: let-7, mir-10a, mir-133a, mir-200b, mir-324, mir-421, mir-23b, and mir-30e. Therefore, these 8 miRNAs are most likely to be key regulators associated with insulin resistance in horses. Additionally, these $8 \mathrm{miRNAs}$ are likely to have great potential as biomarkers for insulin resistance and associated conditions, such as hyperinsulinism, hyperglycemia and obesity, in equids. Unfortunately, there is not much data on equine insulin resistance and miRNA profiles currently available for equids as compared to other species, such as humans and mice.

Because we used circulating miRNA profiles, we are not able to define where these significantly different miRNAs were being release from, which cells they were targeting, and how they were being regulated. Therefore, to confirm our hypothesis, future studies focusing on specific tissue cells and metabolic pathways are required for better understanding the regulation mechanisms involving these miRNAs in equine health and disease.

Although there were differences in the miRNA profile between studies (preliminary and current), both identified differential circulating miRNA profiles between healthy and insulin resistant animals. Several miRNAs identified to be differently expressed between groups have already been reported to be associated with diseases related to insulin resistance. Therefore, these studies support the great potential of miRNAs as tools for predicting and managing insulin resistance and related conditions in horses.

\section{Conclusion}

The results of these studies support a potential novel strategy to study insulin resistance in horses. There is strong evidence supporting association of circulating miRNA profiles with the development of insulin-resistance in horses. Although the use of miRNA as biomarkers for this metabolic condition in equids is still a work in progress, several miRNAs have been identified as possible key regulators in the incidence of the disease, such as let-7, mir-10a, mir-133a, mir-200b, mir-324, mir-421, mir-23b, and mir-30e. Many questions are still waiting to be answered regarding how these miRNAs impact equine insulin resistance. The current study suggests 8 circulating miRNAs as possible key regulators of insulin resistance in horses, which are expected to be used to further investigate the prognosis of equine insulin resistance. Future studies are required to confirm consistency of our results and to identify possible roles miRNAs play in equine health and disease. By identifying the role of miRNAs in equine health and disease, it will be possible to use new strategies to understand the mechanisms involved in equine insulin resistance and associated conditions and to develop practical and efficient diagnosis and prognosis methods for this condition in horses.

\section{Acknowledgements}

Thankful to Virginia Tech Graduate students for helping with data collection, Mrs. Abeles for letting us use the Farnley Farm ponies.

\section{Ethics statement}

This study was approved by the Virginia Tech Institutional Animal Care and Use Committee. IACUC\#: 15-046, Virginia Polytechnic Institute and State University.

\section{Financial support}

This study was partially financed by Grayson Jockey Club Foundation Grant 2014 and Hugo sponsored by the CNPq.

\section{Conflicts of interests}

The authors of this paper have no conflict of interest.

\section{Authors' contributions}

HFCS - Collection of material assay conduction, application of statistics, preparation and writing of initial draft. TMH - Development of methodology, collection of materials, preparation and writing of manuscript, acquisition of the financial support for the project leading to this 
publication. JB - Acquisition of the financial support for the project leading to this publication, laboratory methodology technique development. PG - Laboratory analysis. BM - Development of methodology, collection of materials. RS - Acquisition of the financial support for the project leading to this publication.

\section{Availability of complementary results}

Non applicable.

The study was carried out at Farnley Farm, Whitepost,VA and Middleburg Agricultural Research and Extension Center, Virginia Tech, Middleburg, VA. Data analysis was performed at Colorado State University, Fort Collins, CO.

\section{References}

Ardekani, A. M., \& Naeini, M. M. (2010). The Role of MicroRNAs in Human Diseases. Avicenna Journal of Medical Biotechnology, 2(4), 161-179. http://dx.doi.org/10.1007/978-1-62703-748-8_3. PMid:23407304.

Bailey, S. R., Habershon-Butcher, J. L., Ransom, K. J., Elliott, J., \& Menzies-Gow, N. J. (2008). Hypertension and insulin resistance in a mixed-breed population of ponies predisposed to laminitis. American Journal of Veterinary Research, 69(1), 122-129. http://dx.doi.org/10.2460/ajvr.69.1.122. PMid:18167097.

Bailey, S. R., Rycroft, A., \& Elliott, J. (2002). Production of amines in equine cecal contents in an in vitro model of carbohydrate overload. Journal of Animal Science, 80(10), 2656-2662. http://dx.doi.org/10.2527/2002.80102656x. PMid:12413088.

Bamford, N. J., Potter, S. J., Harris, P. A., \& Bailey, S. R. (2014). Breed differences in insulin sensitivity and insulinemic responses to oral glucose in horses and ponies of moderate body condition score. Domestic Animal Endocrinology, 47, 101-107. http://dx.doi.org/10.1016/j.domaniend.2013.11.001. PMid:24308928.

Becker, N., \& Lockwood, C.M. "Pre-analytical variables in miRNA analysis." Clinical Biochemistry .46,10-11 (2013): 861-8. doi:10.1016/j.clinbiochem.2013.02.015

Borer, K. E., Berhane, Y., Menzies-Gow, N. J., Harris, P. A., \& Elliott, J. (2009) Measurement of concentrations of insulin in equine serum that exceed the working range of radioimmunoassay kits. In: Proceedings of the 48th British Equine Veterinary Association Congress, Equine Veterinary Journal Ltd, Fordham. p 103.

Calvier, L., Chouvarine, P., Legchenko, E., Hoffmann, N., Geldner, J., Borchert, P., Jonigk, D., Mozes, M. M., \& Hansmann, G. (2017). PPAR $\gamma$ Links BMP2 and TGF 31 Pathways in Vascular Smooth Muscle Cells, Regulating Cell Proliferation and Glucose Metabolism. Cell Metabolism, 25(5), 1118-1134.e7. http://dx.doi.org/10.1016/j. cmet.2017.03.011. PMid:28467929.

Chartoumpekis, D. V., Zaravinos, A., Ziros, P.G., Iskrenova, R.P., Psyrogiannis, A.I., Kyriazopoulou, V.E. \& Habeos, I.G. (2012) Differential expression of microRNAs in adipose tissue after long-term high-fat diet-induced obesity in mice. PLoS One 7(4):e34872. http://dx.doi.org/10.1371/journal.pone.0034872.

Chen, G. Q., Lian, W. J., Wang, G. M., Wang, S., Yang, Y. Q., \& Zhao, Z. W. (2012). Altered microRNA expression in skeletal muscle results from high-fat diet-induced insulin resistance in mice. Molecular Medicine Reports, 5(5), 1362-1368. http://dx.doi.org/10.3892/mmr.2012.824. PMid:22395471.

Collares, C. V., Evangelista, A. F., Xavier, D. J., Rassi, D. M., Arns, T., Foss-Freitas, M. C., Foss, M. C., Puthier, D., Sakamoto-Hojo, E. T., Passos, G. A., \& Donadi, E. A. (2013). Identifying common and specific microRNAs expressed in peripheral blood mononuclear cell of type 1, type 2, and gestational diabetes mellitus patients. BMC Research Notes, 6(1), 491. http://dx.doi.org/10.1186/1756-0500-6-491. PMid:24279768.

Cui, X., You, L., Zhu, L., Wang, X., Zhou, Y., Li, Y., Wen, J., Xia, Y., Wang, X., Ji, C., \& Guo, X. (2018). Change in circulating microRNA profile of obese children indicates future risk of adult diabetes. Metabolism: Clinical and Experimental, 78, 95-105. http://dx.doi.org/10.1016/j.metabol.2017.09.006. PMid:28966078.

da Costa Santos, H., Hess, T., Bruemmer, J., \& Splan, R. (2018). Possible role of microRNA in equine insulin resistance: A pilot study. Journal of Equine Veterinary Science, 63, 74-79. http://dx.doi.org/10.1016/j.jevs.2017.10.024.

DeFronzo, R. A., Tobin, J. D., \& Andres, R. (1979). Glucose clamp technique: A method for quantifying insulin secretion and resistance. The American Journal of Physiology, 237(3), E214-E223. http://dx.doi.org/10.1152/ ajpendo.1979.237.3.E214. PMid:382871.

Donaldson, M. T., McDonnell, S. M., Schanbacher, B. J., Lamb, S. V., McFarlane, D., \& Beech, J. (2005). Variation in plasma adrenocorticotropic hormone concentration and dexamethasone suppression test results with season, age, and sex in healthy ponies and horses. Journal of Veterinary Internal Medicine, 19(2), 217-222. http://dx.doi.org/10.1111/j.1939-1676.2005.tb02685.x. PMid:15822567.

Dou, L., Zhao, T., Wang, L., Huang, X., Jiao, J., Gao, D., Zhang, H., Shen, T., Man, Y., Wang, S., \& Li, J. (2013). miR200s contribute to interleukin-6 (IL-6)-induced insulin resistance in hepatocytes. The Journal of Biological Chemistry, 288(31), 22596-22606. http://dx.doi.org/10.1074/jbc.M112.423145. PMid:23798681.

Eder, K., Baffy, N., Falus, A., \& Fulop, A. K. (2009). The major inflammatory mediator interleukin-6 and obesity. Inflammation Research: Official Journal of the European Histamine Research Society ... [et al.], 58(11), 727-736. https://doi.org/10.1007/s00011-009-0060-4. 
Erener, S., Marwaha, A., Tan, R., Panagiotopoulos, C., \& Kieffer, T. J. (2017). Profiling of circulating microRNAs in children with recent onset of type 1 diabetes. JCIInsight,2(4), e89656. http://dx.doi.org/10.1172/jci.insight.89656. PMid:28239651.

Esau, C., Davis, S., Murray, S. F., Yu, X. X., Pandey, S. K., Pear, M., Watts, L., Booten, S. L., Graham, M., McKay, R., Subramaniam, A., Propp, S., Lollo, B. A., Freier, S., Bennett, C. F., Bhanot, S., \& Monia, B. P. (2006). miR-122 regulation of lipid metabolism revealed by in vivo antisense targeting. Cell Metabolism, 3(2), 87-98. http:/l dx.doi.org/10.1016/j.cmet.2006.01.005. PMid:16459310.

Frank, N., Geor, R. J., Bailey, S. R., Durham, A. E., \& Johnson, P. J., \& American College of Veterinary Internal Medicine (2010). Equine metabolic syndrome. Journal of Veterinary Internal Medicine, 24(3), 467-475. http:// dx.doi.org/10.1111/j.1939-1676.2010.0503.x. PMid:20384947.

Freestone, J. F., Shoemaker, K., Bessin, R., \& Wolfsheimer, J. K. (1992). Insulin and glucose response following oral glucose administration in well-conditioned ponies. Equine Veterinary Journal. Supplement, 24(11), 13-17. http://dx.doi.org/10.1111/j.2042-3306.1992.tb04764.x. PMid:9109953.

Frost, R. J., \& Olson, E. N. (2011). Control of glucose homeostasis and insulin sensitivity by the Let-7 family of microRNAs. Proceedings of the National Academy of Sciences of the United States of America, 108(52), 2107521080. http://dx.doi.org/10.1073/pnas.1118922109. PMid:22160727.

Gallagher, I. J., Scheele, C., Keller, P., Nielsen, A. R., Remenyi, J., Fischer, C. P., Roder, K., Babraj, J., Wahlestedt, C., Hutvagner, G., Pedersen, B. K., \& Timmons, J. A. (2010). Integration of microRNA changes in vivo identifies novel molecular features of muscle insulin resistance in type 2 diabetes. Genome Medicine, 2(2), 9. http:// dx.doi.org/10.1186/gm130. PMid:20353613.

Garner, H. E., Hutcheson, D. P., Coffman, J. R., Hahn, A. W., \& Salem, C. (1977). Lactic acidosis: A factor associated with equine laminitis. Journal of Animal Science, 45(5), 1037-1041. http://dx.doi.org/10.2527/jas1977.4551037x. PMid:599094.

Geor, R. J. (2010). Current concepts on the pathophysiology of pasture-associated laminitis. The Veterinary Clinics of North America. EquinePractice,26(2), 265-276. http://dx.doi.org/10.1016/i.cveq.2010.06.001. PMid:20699174.

Geor, R. J. (2013). Endocrine and metabolic physiology. In R. J. Geor, P. A. Harris \& M. Coenen (Eds.), Equine Applied and Clinical Nutrition: Health, Welfare and Performance (pp. 33-63). Filadélfia: W. B. Saunders Company. http:/l dx.doi.org/10.1016/B978-0-7020-3422-0.00002-X.

Herrera, B. M., Lockstone, H. E., Taylor, J. M., Ria, M., Barrett, A., Collins, S., Kaisaki, P., Argoud, K., Fernandez, C., Travers, M. E., Grew, J. P., Randall, J. C., Gloyn, A. L., Gauguier, D., McCarthy, M. I., \& Lindgren, C. M. (2010). Global microRNA expression profiles in insulin target tissues in a spontaneous rat model of type 2 diabetes. Diabetologia, 53(6), 1099-1109. http://dx.doi.org/10.1007/s00125-010-1667-2. PMid:20198361.

Hoffman, R. M., Boston, R. C., Stefanovski, D., Kronfeld, D. S., \& Harris, P. A. (2003). Obesity and diet affect glucose dynamics and insulin sensitivity in Thoroughbred geldings. Journal of Animal Science, 81(9), 2333-2342. http://dx.doi.org/10.2527/2003.8192333x. PMid:12968709.

Jeffcott, L. B., Field, J. R., McLean, J. G., \& O'Dea, K. (1986). Glucose tolerance and insulin sensitivity in ponies and Standardbred horses. Equine Veterinary Journal, 18(2), 97-101. http://dx.doi.org/10.1111/j.2042-3306.1986. tb03556.x. PMid:3516677.

Jiang, L. Q., Franck, N., Egan, B., Sjögren, R. J., Katayama, M., Duque-Guimaraes, D., Arner, P., Zierath, J. R., \& Krook, A. (2013). Autocrine role of interleukin-13 on skeletal muscle glucose metabolism in type 2 diabetic patients involves microRNA let-7. American Journal of Physiology. Endocrinology and Metabolism, 305(11), E1359-E1366. http://dx.doi.org/10.1152/ajpendo.00236.2013. PMid:24105413.

Kahn, B. B., \& Flier, J. S. (2000). Obesity and insulin resistance. The Journal of Clinical Investigation, 106(4), 473481. http://dx.doi.org/10.1172/JCl10842. PMid:10953022.

Kameswaran, V., Bramswig, N. C., McKenna, L. B., Penn, M., Schug, J., Hand, N. J., Chen, Y., Choi, I., Vourekas, A., Won, K. J., Liu, C., Vivek, K., Naji, A., Friedman, J. R., \& Kaestner, K. H. (2014). Epigenetic regulation of the DLK1-MEG3 microRNA cluster in human type 2 diabetic islets. Cell Metabolism, 19(1), 135-145. http://dx.doi. org/10.1016/j.cmet.2013.11.016. PMid:24374217.

Karagkouni, D., Paraskevopoulou, M. D., Chatzopoulos, S., Vlachos, I. S., Tastsoglou, S., Kanellos, I., Papadimitriou, D., Kavakiotis, I., Maniou, S., Skoufos, G., Vergoulis, T., Dalamagas, T., \& Hatzigeorgiou, A. G. (2018). DIANATarBase v8: A decade-long collection of experimentally supported miRNA-gene interactions. Nucleic Acids Research, 46(D1), D239-D245. http://dx.doi.org/10.1093/nar/gkx1141. PMid:29156006.

Karolina, D. S., Armugam, A., Tavintharan, S., Wong, M. T., Lim, S. C., Sum, C. F., \& Jeyaseelan, K. (2011). MicroRNA 144 impairs insulin signaling by inhibiting the expression of insulin receptor substrate 1 in type 2 diabetes mellitus. PLoS One, 6(8), e22839. http://dx.doi.org/10.1371/journal.pone.0022839. PMid:21829658.

Kato, M., Putta, S., Wang, M., Yuan, H., Lanting, L., Nair, I., Gunn, A., Nakagawa, Y., Shimano, H., Todorov, I., Rossi, J. J., \& Natarajan, R. (2009). TGF-beta activates Akt kinase through a microRNA-dependent amplifying circuit targeting PTEN. Nature Cell Biology, 11(7), 881-889. http://dx.doi.org/10.1038/ncb1897. PMid:19543271.

Klöting, N., Berthold, S., Kovacs, P., Schön, M. R., Fasshauer, M., Ruschke, K., Stumvoll, M., \& Blüher, M. (2009). MicroRNA expression in human omental and subcutaneous adipose tissue. PLoS One, 4(3), e4699. http:/l dx.doi.org/10.1371/journal.pone.0004699. PMid:19259271.

Kronfeld, D., \& Harris, P. (2003). Equine grain-associated disorders. The Compendium on Continuing Education for the Practicing Veterinarian, 25, 974-983. 
Lecchi, C., Dalla Costa, E., Lebelt, D., Ferrante, V., Canali, E., Ceciliani, F., Stucke, D., \& Minero, M. (2018). Circulating miR-23b-3p, miR-145-5p and miR-200b-3p are potential biomarkers to monitor acute pain associated with laminitis in horses. Animal: an International Journal of Animal Bioscience, 12(2), 366-375. https://doi.org/10.1017/ S1751731117001525.

Lewis, S. L., Holl, H. M., Streeter, C., Posbergh, C., Schanbacher, B. J., Place, N. J., Mallicote, M. F., Long, M. T., \& Brooks, S. A. (2017). Genomewide association study reveals a risk locus for equine metabolic syndrome in the Arabian horse. Journal of Animal Science, 95(3), 1071-1079. http://dx.doi.org/10.2527/jas2016.1221. PMid:28380523.

Li, A., Qiu, M., Zhou, H., Wang, T., \& Guo, W. (2017). PTEN, insulin resistance and cancer. Current Pharmaceutical Design, 23(25), 3667-3676. http://dx.doi.org/10.2174/1381612823666170704124611. PMid:28677502.

Li, Z. Y., Na, H. M., Peng, G., Pu, J., \& Liu, P. (2011). Alteration of microRNA expression correlates to fatty acidmediated insulin resistance in mouse myoblasts. Molecular BioSystems, 7(3), 871-877. http://dx.doi.org/10.1039/ COMB00230E. PMid:21183973.

Lindåse, S., Müller, C., Nostell, K., \& Bröjer, J. (2018). Evaluation of glucose and insulin response to haylage diets with different content of nonstructural carbohydrates in 2 breeds of horses. Domestic Animal Endocrinology, 64, 49-58. http://dx.doi.org/10.1016/j.domaniend.2018.03.006. PMid:29751248.

Liu, W., Bi, P., Shan, T., Yang, X., Yin, H., Wang, Y. X., Liu, N., Rudnicki, M. A., \& Kuang, S. (2013). miR-133a regulates adipocyte browning in vivo. PLOS Genetics, 9(7), e1003626. http://dx.doi.org/10.1371/journal.pgen.1003626. PMid:23874225.

Locke, J. M., da Silva Xavier, G., Dawe, H. R., Rutter, G. A., \& Harries, L. W. (2014). Increased expression of miR187 in human islets from individuals with type 2 diabetes is associated with reduced glucose-stimulated insulin secretion. Diabetologia, 57(1), 122-128. http://dx.doi.org/10.1007/s00125-013-3089-4. PMid:24149837.

Longland, A. C., \& Byrd, B. M. (2006). Pasture nonstructural carbohydrates and equine laminitis. The Journal of Nutrition, 136(7, Suppl), 2099S-2102S. http://dx.doi.org/10.1093/jn/136.7.2099S. PMid:16772510.

Mao, Y., Mohan, R., Zhang, S., \& Tang, X. (2013). MicroRNAs as pharmacological targets in diabetes. Pharmacological Research, 75, 37-47. http://dx.doi.org/10.1016/j.phrs.2013.06.005. PMid:23810798.

Massart, J., Katayama, M., \& Krook, A. (2016). microManaging glucose and lipid metabolism in skeletal muscle: Role of microRNAs. Biochimica et Biophysica Acta, 1861(12, 12 Pt B), 2130-2138. http://dx.doi.org/10.1016/j. bbalip.2016.05.006. PMid:27183241.

McFarlane, D., Paradis, M. R., Zimmel, D., Sykes, B., Brorsen, B. W., Sanchez, A., \& Vainio, K. (2011). The effect of geographic location, breed, and pituitary dysfunction on seasonal adrenocorticotropin and $\alpha$-melanocytestimulating hormone plasma concentrations in horses. Journal of Veterinary Internal Medicine, 25(4), 872-881. http://dx.doi.org/10.1111/j.1939-1676.2011.0745.x. PMid:21745243.

McGowan, C. M., Frost, R., Pfeiffer, D. U., \& Neiger, R. (2004). Serum insulin concentrations in horses with equine Cushing's syndrome: Response to a cortisol inhibitor and prognostic value. Equine Veterinary Journal, 36(3), 295-298. http://dx.doi.org/10.2746/0425164044877288. PMid:15147141.

Meshkani, R., \& Adeli, K. (2009). Hepatic insulin resistance, metabolic syndrome and cardiovascular disease. Clinical Biochemistry, 42(13-14), 1331-1346. http://dx.doi.org/10.1016/j.clinbiochem.2009.05.018. PMid:19501581.

Mestdagh, P., Van Vlierberghe, P., De Weer, A., Muth, D., Westermann, F., Speleman, F., \& Vandesompele, J. (2009). A novel and universal method for microRNA RT-qPCR data normalization. Genome Biology, 10(6), R64. http:/l dx.doi.org/10.1186/gb-2009-10-6-r64. PMid:19531210.

Metson, A. J., Gibson, E. J., Hunt, J. L. \& Saunders, W. M. H. (1979) Seasonal variations in chemical composition of pasture. New Zealand Journal of Agricultural Research, 22(2), 309-318. http://dx.doi.org/10.1080/002882 33.1979.10430752.

Morgan, R., Keen, J., \& McGowan, C. (2015). Equine metabolic syndrome. The Veterinary Record, 177(7), 173-179. http://dx.doi.org/10.1136/vr.103226. PMid:26273009.

Nakanishi, N., Nakagawa, Y., Tokushige, N., Aoki, N., Matsuzaka, T., Ishii, K., Yahagi, N., Kobayashi, K., Yatoh, S., Takahashi, A., Suzuki, H., Urayama, O., Yamada, N., \& Shimano, H. (2009). The up-regulation of microRNA-335 is associated with lipid metabolism in liver and white adipose tissue of genetically obese mice. Biochemical and Biophysical Research Communications, 385(4), 492-496. http://dx.doi.org/10.1016/j.bbrc.2009.05.058. PMid:19460359.

Nakashima, N., Sharma, P. M., Imamura, T., Bookstein, R., \& Olefsky, J. M. (2000). The tumor suppressor PTEN negatively regulates insulin signaling in 3T3-L1 adipocytes. The Journal of Biological Chemistry, 275(17), 12889-12895. http://dx.doi.org/10.1074/jbc.275.17.12889. PMid:10777587.

Nirmalan, N., \& Nirmalan, M. (2017). Hormonal control of metabolism: Regulation of plasma glucose. Anaesthesia and Intensive Care Medicine, 18(10), 502-507. http://dx.doi.org/10.1016/j.mpaic.2017.06.019.

Nulton, L. (2014). Cross-kingdom microRNA detection and influence of dieton endogenous equine micrornas [Master thesis, Colorado State University]. 2000-2019- CSU Theses and Dissertations. https://mountainscholar.org/ handle/10217/100538

Ortega, F. J., Mercader, J. M., Catalán, V., Moreno-Navarrete, J. M., Pueyo, N., Sabater, M., Gómez-Ambrosi, J., Anglada, R., Fernández-Formoso, J. A., Ricart, W., Frühbeck, G., \& Fernández-Real, J. M. (2013). Targeting the circulating microRNA signature of obesity. Clinical Chemistry, 59(5), 781-792. http://dx.doi.org/10.1373/ clinchem.2012.195776. PMid:23396142. 
Ortega, F. J., Mercader, J. M., Moreno-Navarrete, J. M., Rovira, O., Guerra, E., Esteve, E., Xifra, G., Martínez, C., Ricart, W., Rieusset, J., Rome, S., Karczewska-Kupczewska, M., Straczkowski, M., \& Fernández-Real, J. M. (2014). Profiling of circulating microRNAs reveals common microRNAs linked to type 2 diabetes that change with insulin sensitization. Diabetes Care, 37(5), 1375-1383. http://dx.doi.org/10.2337/dc13-1847. PMid:24478399.

Pacholewska, A., Mach, N., Mata, X., Vaiman, A., Schibler, L., Barrey, E., \& Gerber, V. (2016). Novel equine tissue miRNAs and breed-related miRNA expressed in serum. BMC Genomics, 17(1), 831. http://dx.doi.org/10.1186/ s12864-016-3168-2. PMid:27782799.

Pando, R., Even-Zohar, N., Shtaif, B., Edry, L., Shomron, N., Phillip, M., \& Gat-Yablonski, G. (2012). MicroRNAs in the growth plate are responsive to nutritional cues: Association between miR-140 and SIRT1. The Journal of Nutritional Biochemistry, 23(11), 1474-1481. http://dx.doi.org/10.1016/j.jnutbio.2011.09.010. PMid:22402365.

Pescador, N., Pérez-Barba, M., Ibarra, J. M., Corbatón, A., Martínez-Larrad, M. T., \& Serrano-Ríos, M. (2013). Serum circulating microRNA profiling for identification of potential type 2 diabetes and obesity biomarkers. PLoS One, 8(10), e77251. http://dx.doi.org/10.1371/journal.pone.0077251. PMid:24204780.

Pfeifer, M. A., Halter, J. B., \& Porte Junior, D. (1981). Insulin secretion in diabetes mellitus. The American Journal of Medicine, 7O(3), 579-588. http://dx.doi.org/10.1016/0002-9343(81)90579-9. PMid:7011013.

Piñero, J., Queralt-Rosinach, N., Bravo, À., Deu-Pons, J., Bauer-Mehren, A., Baron, M., Sanz, F., \& Furlong, L. I. (2015). DisGeNET: a discovery platform for the dynamical exploration of human diseases and their genes. Database: The Journal of Biological Databases and Curation, 2015, bav028. https://doi.org/10.1093/database/bav028.

Piñero, J., Bravo, À., Queralt-Rosinach, N., Gutiérrez-Sacristán, A., Deu-Pons, J., Centeno, E., García-García, J., Sanz, F., \& Furlong, L. I. (2017). DisGeNET: A comprehensive platform integrating information on human disease-associated genes and variants. Nucleic Acids Research, 45(D1), D833-D839. http://dx.doi.org/10.1093/ nar/gkw943. PMid:27924018.

Prabu, P., Rome, S., Sathishkumar, C., Aravind, S., Mahalingam, B., Shanthirani, C. S., Gastebois, C., Villard, A., Mohan, V., \& Balasubramanyam, M. (2015). Circulating MiRNAs of 'Asian Indian Phenotype' Identified in Subjects with Impaired Glucose Tolerance and Patients with Type 2 Diabetes. PLoS One, 10(5), e0128372. http://dx.doi.org/10.1371/journal.pone.0128372. PMid:26020947.

Rasmussen, J. J., Schou, M., Selmer, C., Johansen, M. L., Gustafsson, F., Frystyk, J., Dela, F., Faber, J., \& Kistorp, C. (2017). Insulin sensitivity in relation to fat distribution and plasma adipocytokines among abusers of anabolic androgenic steroids. Clinical Endocrinology, 87(3), 249-256. http://dx.doi.org/10.1111/cen.13372. PMid:28500659.

Reczko, M., Maragkakis, M., Alexiou, P., Grosse, I., \& Hatzigeorgiou, A. G. (2012). Functional microRNA targets in protein coding sequences. Bioinformatics (Oxford, England), 28(6), 771-776. http://dx.doi.org/10.1093/ bioinformatics/bts043. PMid:22285563.

Sah, S. P., Singh, B., Choudhary, S., \& Kumar, A. (2016). Animal models of insulin resistance: A review. Pharmacological reports: $P R, 68(6), 1165-1177$. https://doi.org/10.1016/j.pharep.2016.07.010.

Shan, Q., Zheng, G., Zhu, A., Cao, L., Lu, J., Wu, D., Zhang, Z., Fan, S., Sun, C., Hu, B., \& Zheng, Y. (2016). Epigenetic modification of miR-1Oa regulates renal damage by targeting CREB1 in type 2 diabetes mellitus. Toxicology and Applied Pharmacology, 306, 134-143. http://dx.doi.org/10.1016/j.taap.2016.06.010. PMid:27292126.

Shao, Y., Ren, H., Lv, C., Ma, X., Wu, C., \& Wang, Q. (2017). Changes of serum Mir-217 and the correlation with the severity in type 2 diabetes patients with different stages of diabetic kidney disease. Endocrine, 55(1), 130-138. http://dx.doi.org/10.1007/s12020-016-1069-4. PMid:27522360.

Sun, J., Li, Z. P., Zhang, R. Q., \& Zhang, H. M. (2017). Repression of miR-217 protects against high glucose-induced podocyte injury and insulin resistance by restoring PTEN-mediated autophagy pathway. Biochemical and Biophysical Research Communications, 483(1), 318-324. http://dx.doi.org/10.1016/j.bbrc.2016.12.145. PMid:28017719.

Tai, M. M. (1994). A mathematical model for the determination of total area under glucose tolerance and other metabolic curves. Diabetes Care, 17(2), 152-154. http://dx.doi.org/10.2337/diacare.17.2.152. PMid:8137688.

Tijsen, A. J., Creemers, E. E., Moerland, P. D., de Windt, L. J., van der Wal, A. C., Kok, W. E., \& Pinto, Y. M. (2010). MiR423-5p as a circulating biomarker for heart failure. Circulation Research, 106(6), 1035-1039. http://dx.doi. org/10.1161/CIRCRESAHA.110.218297. PMid:20185794.

Trajkovski, M., Hausser, J., Soutschek, J., Bhat, B., Akin, A., Zavolan, M., Heim, M. H., \& Stoffel, M. (2011). MicroRNAs 103 and 107 regulate insulin sensitivity. Nature, 474(7353), 649-653. http://dx.doi.org/10.1038/nature10112. PMid:21654750.

Treiber, K. H., Kronfeld, D. S., Hess, T. M., Boston, R. C., \& Harris, P. A. (2005). Use of proxies and reference quintiles obtained from minimal model analysis for determination of insulin sensitivity and pancreatic beta-cell responsiveness in horses. American Journal of Veterinary Research, 66(12), 2114-2121. http://dx.doi. org/10.2460/ajvr.2005.66.2114. PMid:16379656.

Vick, M. M., Adams, A. A., Murphy, B. A., Sessions, D. R., Horohov, D. W., Cook, R. F., Shelton, B. J., \& Fitzgerald, B. P. (2007). Relationships among inflammatory cytokines, obesity, and insulin sensitivity in the horse. Journal of Animal Science, 85(5), 1144-1155. http://dx.doi.org/10.2527/jas.2006-673. PMid:17264235.

Vlachos, I. S., Zagganas, K., Paraskevopoulou, M. D., Georgakilas, G., Karagkouni, D., Vergoulis, T., Dalamagas, T., \& Hatzigeorgiou, A. G. (2015). DIANA-miRPath v3.0: Deciphering microRNA function with experimental support. Nucleic Acids Research, 43(W1), W460-W466. http://dx.doi.org/10.1093/nar/gkv403. PMid:25977294. 
Wang, C., Wan, S., Yang, T., Niu, D., Zhang, A., Yang, C., Cai, J., Wu, J., Song, J., Zhang, C. Y., Zhang, C., \& Wang, J. (2016). Increased serum microRNAs are closely associated with the presence of microvascular complications in type 2 diabetes mellitus. Scientific Reports, 6(1), 20032. http://dx.doi.org/10.1038/srep20032. PMid:26831044.

Wilcox, G. (2005). Insulin and insulin resistance. The Clinical biochemist. Reviews / Australian Association of Clinical Biochemists, 26(2), 19-39. PMid:16278749.

Williams, M. D., \& Mitchell, G. M. (2012). MicroRNAs in insulin resistance and obesity. Experimental Diabetes Research, 2012, 484696. http://dx.doi.org/10.1155/2012/484696. PMid:22851965.

Witwer, K. W. (2012). XenomiRs and miRNA homeostasis in health and disease: Evidence that diet and dietary miRNAs directly and indirectly influence circulating miRNA profiles. RNA Biology, 9(9), 1147-1154. http:// dx.doi.org/10.4161/rna.21619. PMid:22951590.

Yang, W. M., Jeong, H. J., Park, S. W., \& Lee, W. (2015). Obesity-induced miR-15b is linked causally to the development of insulin resistance through the repression of the insulin receptor in hepatocytes. Molecular Nutrition \& Food Research, 59(11), 2303-2314. http://dx.doi.org/10.1002/mnfr.201500107. PMid:26179126.

[[Q12: Q12]]Yang, W. M., Jeong, H. J., Park, S. Y., \& Lee, W. (2014). Saturated fatty acid-induced miR-195 impairs insulin signaling and glycogen metabolism in HepG2 cells. FEBS Letters, 588(21), 3939-3946. http://dx.doi. org/10.1016/j.febslet.2014.09.006. PMid:25240198.

Yang, W. M., Min, K. H., \& Lee, W. (2016). MicroRNA expression analysis in the liver of high fat diet-induced obese mice. Data in Brief, 9, 1155-1159. http://dx.doi.org/10.1016/j.dib.2016.11.081. PMid:27995171.

Yi, F., Shang, Y., Li, B., Dai, S., Wu, W., Cheng, L., \& Wang, X. (2017). MicroRNA-193-5p modulates angiogenesis through IGF2 in type 2 diabetic cardiomyopathy. Biochemical and Biophysical Research Communications, 491(4), 876-882. http://dx.doi.org/10.1016/j.bbrc.2017.07.108. PMid:28735866.

Ying, W., Tseng, A., Chang, R. C. A., Wang, H., Lin, Y. L., Kanameni, S., Brehm, T., Morin, A., Jones, B., Splawn, T., Criscitiello, M., Golding, M. C., Bazer, F. W., Safe, S., \& Zhou, B. (2016). MiR-150 regulates obesity-Associated insulin resistance by controlling B cell functions. Scientific Reports, 6(20176), 20176. http://dx.doi.org/10.1038/ srep20176. PMid:26833392.

Zhou, M., Wang, Q., Sun, J., Li, X., Xu, L., Yang, H., Shi, H., Ning, S., Chen, L., Li, Y., He, T., \& Zheng, Y. (2009). In silico detection and characteristics of novel microRNA genes in the Equus caballus genome using an integrated ab initio and comparative genomic approach. Genomics, 94(2), 125-131. http://dx.doi.org/10.1016/j. ygeno.2009.04.006. PMid:19406225.

Zhu, H., \& Leung, S. W. (2015). Identification of microRNA biomarkers in type 2 diabetes: A meta-analysis of controlled profiling studies. Diabetologia, 58(5), 900-911. http://dx.doi.org/10.1007/s00125-015-3510-2. PMid:25677225. 